\title{
Population, aquaculture and transplantation applications of critically endangered species Pinna nobilis (Linnaeus 1758) in the Mediterranean Sea
}

\author{
Sefa Acarli ${ }^{1^{*}}$ \\ ${ }^{1}$ Çanakkale Onsekiz Mart University, Faculty of Marine Sciences and Technology, Department of Aquaculture, 17020, Çanakkale, \\ Turkey
}

\begin{tabular}{l} 
A R T I C L E I N F O \\
\hline Article History: \\
Received: 01.10 .2019 \\
Received in revised form: 01.11 .2021 \\
Accepted: 01.11 .2021 \\
Available online: 23.11 .2021
\end{tabular}

Keywords:
Critically endangered species
Pinna nobilis
Fan mussel
Aquaculture
Transplantation

\begin{abstract}
A B S T R A C T
The population of fan mussel, Pinna nobilis across the Mediterranean Sea has been affected by factors such as overfishing, fisheries processes, environmental pollution, destruction of habitat, tourism, etc. Therefore, the species $P$. nobilis was taken under protection by the Decisions of the Council of Europe and Barcelona Convention. However, its mortality rates of $100 \%$ have been reported to be due to Haplosporidium pinnae, a parasite in different Mediterranean regions. The status of $P$. nobilis has thus been revised to be reduced from "Vulnerable" to "Critically Endangered" and the importance of all the studies on the species further increased. The aim of the study is to present the current status of $P$. nobilis, the native to the Mediterranean, by combining the relevant studies on ecology, aquacultural process (larvae, spat settlement and rearing), culture methods and transplantation. The present study has provided comprehensive knowledge on the current status $P$. nobilis population, aquaculture and transplantation activities. Except for studies to determine stocks, in particular, those on collecting young individuals from nature and planting and growing them in predetermined sites as well as their production through various cultures from their larval phase onwards are of great importance in terms of rehabilitation and sustenance of the damaged $P$. nobilis population. Therefore, alternative and potential habitats should be created thanks to transplantation and aquaculture. Marine protected areas should be determined to enable a healthy $P$. nobilis population to be sustained.
\end{abstract}

Please cite this paper as follows:

Acarli, S. (2021). Population, aquaculture and transplantation applications of critically endangered species Pinna nobilis (Linnaeus 1758) in the Mediterranean Sea. Marine Science and Technology Bulletin, 10(4), 350-369. https://doi.org/10.33714/masteb.627562

\footnotetext{
* Corresponding author

E-mail address: sefaacarli@comu.edu.tr (S. Acarli)
} 


\section{Introduction}

Fan mussels under the classis of Bivalvia are represented by the species of Pinna nobilis (Linnaeus 1758), Pinna rudis (Linnaeus 1758) and Atrina fragilis (Pennant 1777) in the Mediterranean basin. A. fragilis has distributed in southeast Africa, New Zealand, North Japan and East Coasts of Atlantic and $P$. rudis across East and West Atlantic, North American and South European shores while $P$. nobilis is native to the Mediterranean Sea. The species of the Pinnidae family are called fan mussel and noble pen shell. In recent years, $P$. nobilis population has significantly decreased along some Mediterranean seashores of France, Greece, Spain, Italy and Croatia (Vicente \& Moreteau, 1991; Catanese et al., 2018). In other regions, its population density decreased from 17 individuals per $100 \mathrm{~m}^{2}$ (Richardson et al., 1999) to 1 individual per $100 \mathrm{~m} 2$ (Katsanevakis \& Thessalou-Legaki, 2009). The future of the species has been established to be "Endangered" for the reasons below;

- various human activities have caused the destruction of coastal habitat,

- increased water pollution,

- damage due to fisheries activities,

- popular consumption of its delicious white muscular meat

- uses of pearly shells in weaving decorative and byssus threads into cloths,

- deep anchor dragging from boats to the destroy fan mussels to death,

- its usages as angling bait to lure and catch fish (Vincente \& Moreteau, 1991; Hendriks et al., 2013; Deudero et al., 2015; Capó et al., 2015).

Considering the above all, $P$. nobilis has been listed as the species endangered in the Mediterranean ecosystem and thus taken under strict protection according to Annex II of the Barcelona Convention (SPA/BD Protocol 1995) and the European Council Directive 92/43/EEC (Annex IV). In addition, the central marine zone and southernmost coasts of the Iberian Peninsula (Spanish Western Mediterranean) showed a $100 \%$ mortality in all length groups of the population (Vázquez-Luis et al., 2017). The status of the species was therefore reconsidered to be increased from "Vulnerable" to "Critically Endangered" at national level by the Spanish Sectorial Environmental Conference on July 17/2017. Darriba (2017) was the first to report the presence of haplosporidan parasite as the earliest histopathology. Haplosporidium pinnae, a species of Haplosporidium parasite in particular has significantly damaged $P$. nobilis population over the last five years. Occasional western Mediterranean and the Tyrrhenian Sea in Italy have recently exhibited 100\% mortalities (Catanese et al., 2018; Carella et al., 2019). Moreover, Katsanevakis et al. (2019) performed a study on mass mortalities of $P$. nobilis in and around the island of Lesvos in the Northern Aegean Sea However, many surviving individuals have been documented in France Port-Cros Archipelago Marine Protected Area (Ruitton \& Lefebvre, 2021), Thau Lagoon (Foulquié et al., 2020), and the East of Corsica Diana Lagoon (Simide et al., 2019), in Spain Alfacts Bay (Ebro Delta) (Prado et al., 2020) and in Greek Kalloni Gulf and Laganas Bay (Zotou et al., 2020). Different stations in the Aegean Sea coasts of Turkey were recorded to exhibit $100 \%$ mortalities (Acarli et al., 2020; Öndes et al., 2020) whereas the Aegean and Marmara mouths of Çanakkale Strait showed mortalities of $100 \%$ and $9.2 \%$ in 2020 , respectively (Acarli et al., 2021a). Künili et al. (2021) mention that $H$. pinnae infected $P$ nobils individuals and caused death in Çanakkale Strait. In addition, Cinar et al. (2021) indicated that at seven locations, a total of 191 P. nobilis individuals were discovered, with $88 \%$ of them being dead in the Marmara Sea. The authors claimed that the cause of mortality could be linked to an epidemic sickness or a catastrophic mucilage occurrence after November 2020. Recently, Acarli et al. (2021b) investigated the effects of the mucilage event on the population of critically endangered Pinna nobilis in Ocaklar Bay (Marmara Sea, Turkey) and the authors documented that the mortality rate was found $35.96 \%$ before the mucilage event while it was calculated as $16.12 \%$ after the mucilage event in the study area. Acarli et al. (2021b) asserted that the P. nobilis population could be resistant to extreme environmental stress and even juvenile individuals (smaller than $15 \mathrm{~cm}$ ) were recruited in the study area during the mucilage event.

The intense amount of mucilage organic matter due to planktonic algal bloom was first reported in mid-autumn 2007 for the Marmara Sea (Aktan et al., 2008). However, mucilage was observed to be more intense in the Marmara Sea this year than in the previous years (Balkıs-Ozdelice et al., 2021). The planktonic algal bloom occurs as the result of higher seawater temperatures, agricultural activities, domestic and industrial waste discharges, and overfishing (Flander-Putrle \& Malej, 2008; Savun-Hekimoğlu \& Gazioğlu, 2021). Benthic organisms are the most affected by the mucilage sunken or accumulated on the bottom (Schiaparelli et al., 2007). It has been observed that $P$. nobilis covered of mucilage, one of the benthic organisms in the coast of Erdek-Ocaklar Bay in the south of 


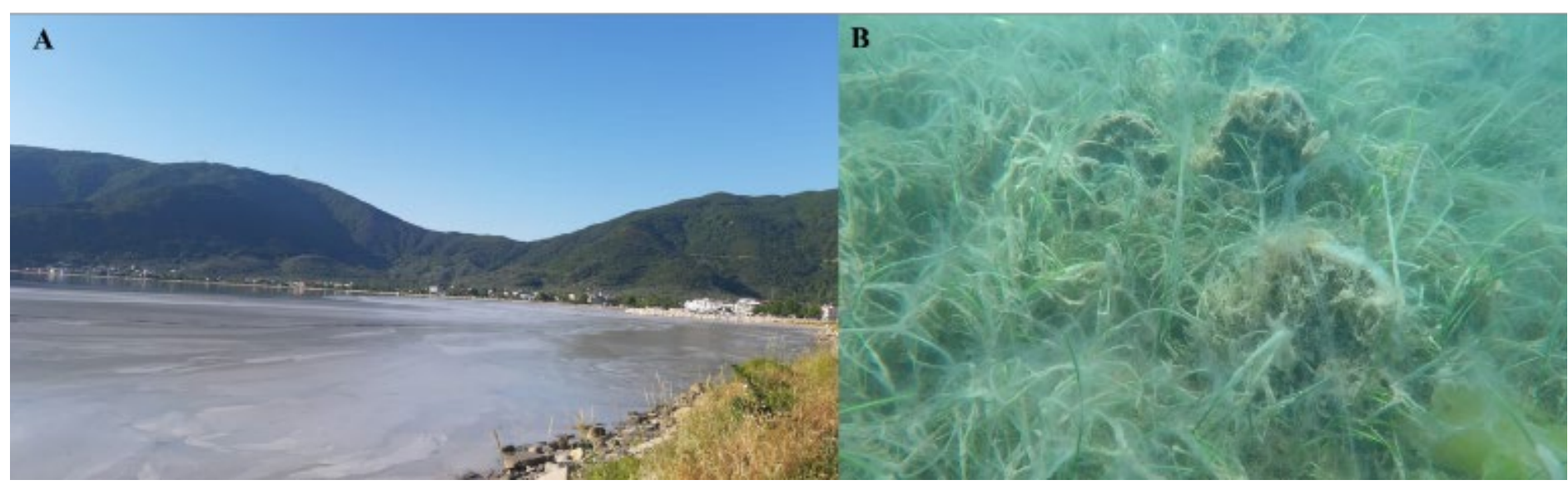

Figure 1. Mucilage on the sea surface of the Erdek-Ocaklar Bay in May, 2021 (A) and underwater view of mucilage on P. nobilis and Posidonia oceonica in the Erdek-Ocaklar Bay in June 2021 (B)

Marmara Sea in March 2021 (Figure 1), effects of which this event will later be understood more clearly.

P. nobilis hosts various species of microorganisms thanks to the width of its surface area and structure of calcium carbonate as well as its individual contributions (Acarli et al., 2010). The associated studies found that species of Bivalvia, Gastropoda, Ascidiacea, Polyplacophora, Echinodermata, Demospongiae, Gymnolaemata, Maxillopoda, Polychaeta, Cyanobacteria, Anthozoa and macroalgae were covered on the shells of the $P$. nobilis (Giacobbe, 2002; Addis et al., 2009; Acarli et al., 2010; Rabaoui, et al., 2015). The present study exhibited that any damages to $P$. nobilis population expose to macrobenthic species on its shell to danger as well.

The purpose of the present paper is (i) to summarize the basic information to recognize the species, (ii) to define the culture methods applied considering other pinna species and to reveal the importance of its aquaculture in conservation programs, and (iii) to define the role and importance of transplantation studies as part of rehabilitation programs.

\section{General Characteristics of Fan Mussels}

\section{Morphology}

Pinnids are of a triangular shape due to their adaptation to tying to the substrate via byssal threads (Figure 2). Generally, the shell has many functions, including serving as a skeleton for attaching muscles, protecting against predators and in burrowing species, and helping keep mud and sand of the mantle cavity (Gosling, 2003). It is composed of three layers: an outer horny periostracum and two calcified layers beneath it. The inner layer is consisting of aragonitic nacre, which is only found in the anterior part of the shell (García-March \& Vicente, 2006). The ligament is located in the dorsal region with the mere function to hold the valves together. The ventral part of the shell has a small opening for the byssus to exit. Byssus consists of many filamentous fibrils that could grow up to 16 cm. Byssal extensions have sticky discs on each (de Gaulejac, 1993).

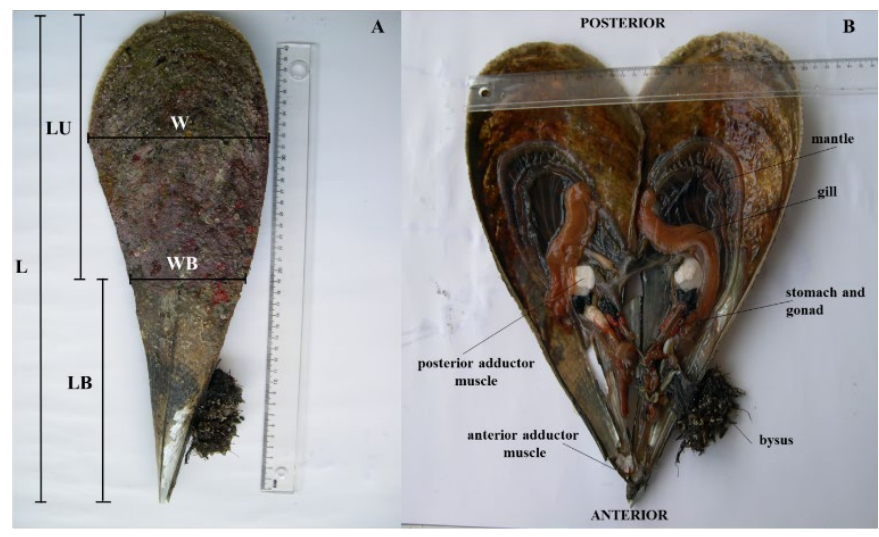

Figure 2. Morphometric parameters (A) and internal organs (B) of $P$. nobilis ( $L$ : total length; $L B$ : bury in shell length; $L U$ : unbury in shell length; W: width; WB: bury in shell width)

Members of the Pinnidae have two adductor muscles: the large posterior adductor is powerful and centrally located in the shell and the small anterior one is located at the umbonal vertex (Grave 1911; Coronel, 1981 in Escamilla-Montes et al., 2017). The posterior adductor and posterior foot retractor muscles are so close to each other that they appear to be one muscle (Czihak \& Dierl, 1961 as cited in Basso et al., 2015). The mantle is not attached to the shell as occurs in other species (e.g., some Mytilidae) and therefore it is very retractable and without a pallial line (García-March, 2005).

The Pinnidae are characterized by waste channels, the ducts through the mantle in an antero-posterior direction from the palps to the of the mouth to the contact with the posteriordorsal end of the gills, in which they combine with the inner lobe of the mantle edge to finally complete the division between the inhalant and exhaling chambers. These channels allow the 
removal of pseudo feces and other debris from the inhalant chamber and can be used to clean the cavity of sand and debris introduced by the waves during storms before closing the leaflets (García-March, 2005).

P. nobilis' functional morphology, in particular the unique pallial organ, the equally unparalleled buccal (previously pallial) gland, stomach and its contents are described (Morton \& Pulijas, 2019). The function of the pallial organ has been controversial over time. It was previously believed to be a cleaning organ responsible for extracting the broken pieces of the shell in the pallial cavity (Yonge, 1953). However, later, it was discovered in Atrina pectinata that the organ proves thigmotropic and highly secretory, with a $\mathrm{pH}$ in its head of 2 to 4 , and it is therefore supposed to have a defensive function, to protect the animal from the entry of epibionts and predator attacks (Liang \& Morton, 1988). In addition, Morton \& Pulijas (2019) found that the pallial gland produces sulphuric acid that engaged in prey capture and function as a shell cleansing pad.

\section{Habitat}

Fan mussels are generally brown, transparently beige to white and yellow in color and fanlike in shape. They are known to be able to live in the depth of $60 \mathrm{~m}$ regardless of variations in species and age. Umbonally attached to and partly embedded in the ground by their byssal threads (Figure 1), they inhabit areas of sandy, sandy pebbled and muddy seabed through seaweeds, Posidonia oceanica (Figure 3) (Tebble, 1966; García-March \& Vicente, 2006).

Though variable in size, their lengths range from 20 to 40 $\mathrm{cm}$ (Fischer, 1987). P. nobilis is known to live until 45 years with a maximum (Rouanet et al., 2015) length of $120 \mathrm{~cm}$ (Zavodnik et al., 1991). It is necessary to count adductor muscle scar rings inside the shell to determine the age of an individual fan mussel. Because the first year-scar ring is invisible or too vague to notice, the age of the fan mussel is determined by adding 1 age to already counted scar rings (Richardson et al., 1999).

Nepinnotheres pinnotheres (Crustacea: Decapoda) (Linnaeus 1758) is known as pinna pea crab brown in color (Hayward \& Ryland, 1995) (Figure 3), which is a parasitic species found in the mantle cavity of $P$. nobilis (Becker \& Turkay, 2017). The adult female is significantly bigger than the mature male (Becker \& Türkay, 2017). N. pinnotheres is believed to live within $P$. nobilis as a temporary refuge. Therefore, more than one male pinna pea crab has been encountered within the same $P$. nobilis individual (Rabaoui et al., 2008). Acarli et al. (2019) reported that N. pinnotheres did not directly influence the intact $P$. nobilis since damages to the tissue of the infected fan mussels were in the process of the study. On the other hand, the same researchers noted that the physical condition of fan mussels might be threatened by adverse environmental conditions or invasion of infectious diseases such as mycobacterium and haplosporidian parasites.

\section{Feeding}

P. nobilis is a suspension feeder or filter feeder organism that feeds on suspended organic and inorganic matters, zooplankton, phytoplankton, bacteria, and viruses in the water column (Gosling, 2003; Davenport et al., 2011; Najdek et al., 2013; Trigos et al., 2014). Thus, it contributes to the improvement of water quality, playing a vital role in the ecology of the Mediterranean Sea (Natalotto et al., 2015). Gills are equipped with functions of feeding and respiration. Food particles captured by the mantle and gills and covered with

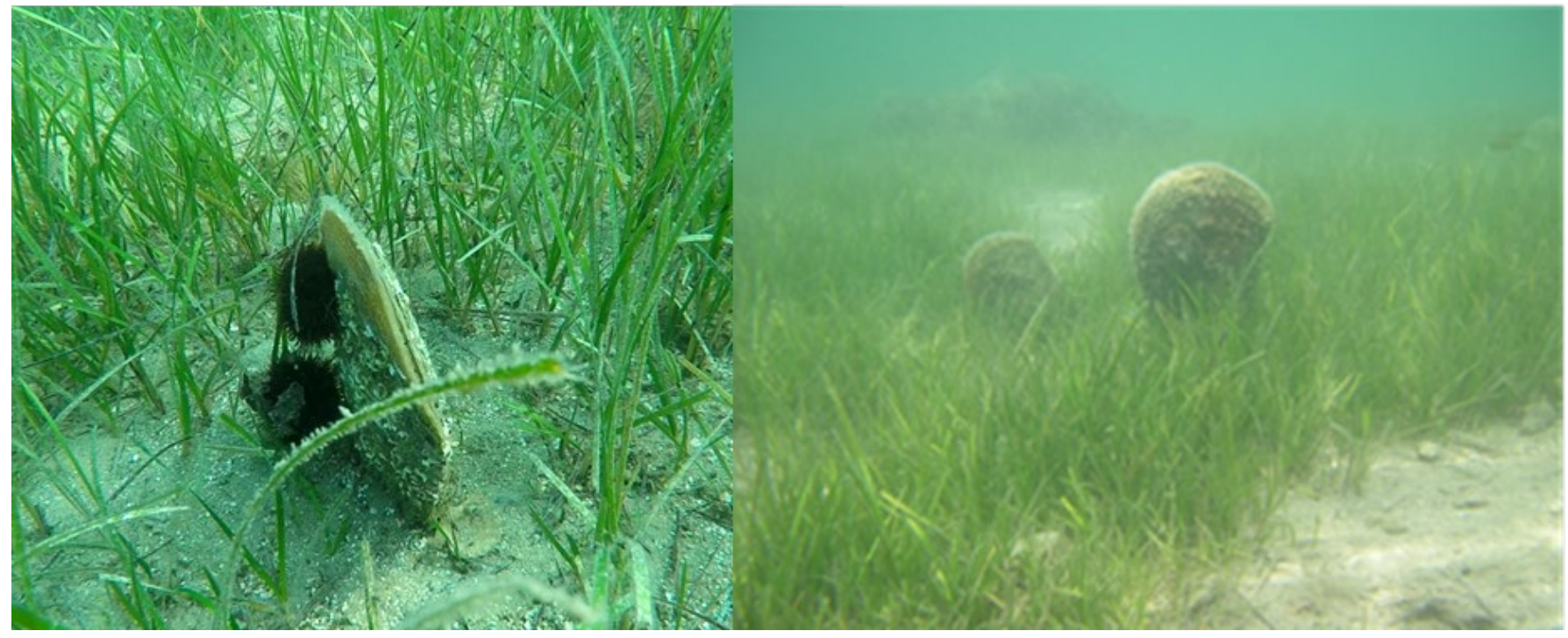

Figure 3. Pinna nobilis on the seagrass meadows (Posidonia oceanica) in the Karantina Island (İzmir Bay, Aegean Sea) in 2008 


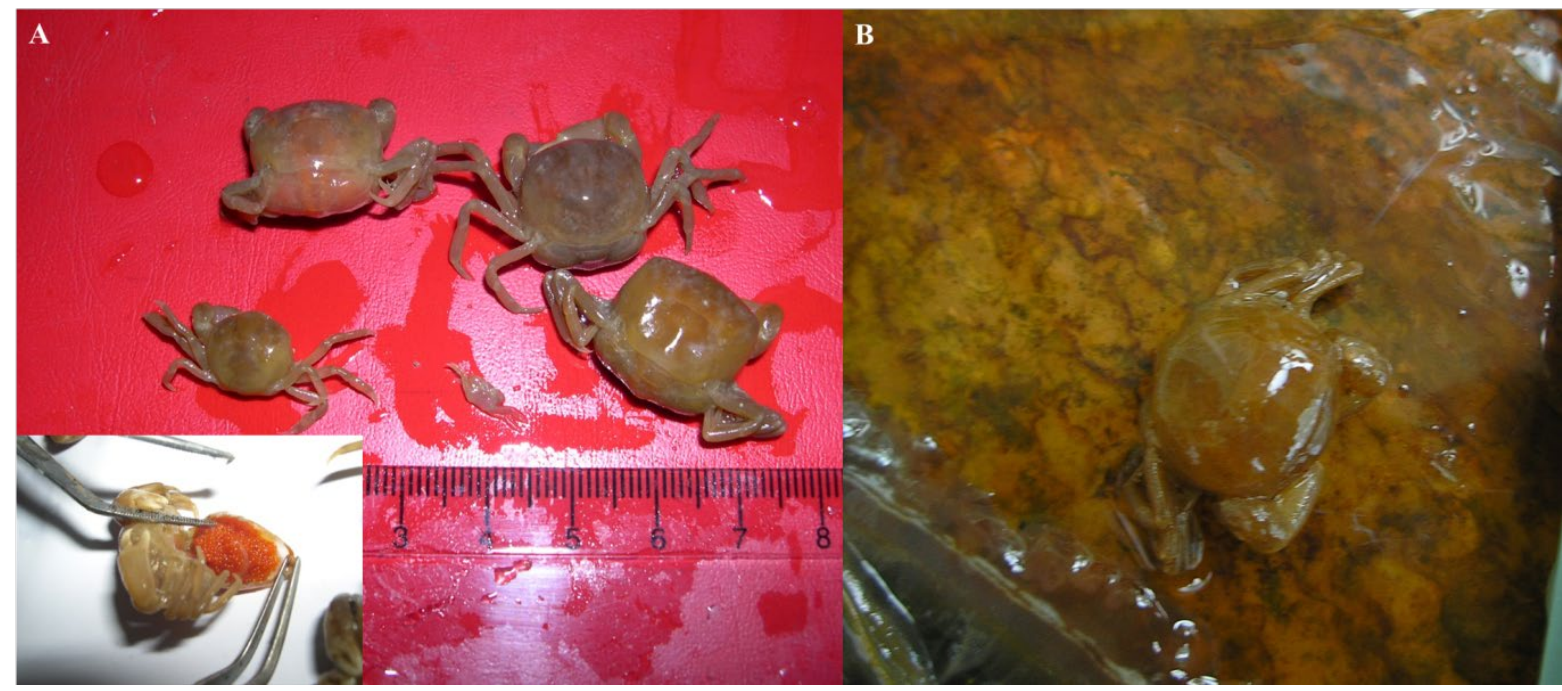

Figure 4. Photographs of N. pinnotheres (A) and N. pinnotheres on the P. nobilis inner shell (B)

mucus are transported by actions of cilia in the gills to labial palps through which they would be selected and processed. While discarded particles are moved to the sides of the palps, those suitable to be ingested are carried to the mouth, from which they pass through the stomach where they are digested by digestive enzymes. Indigestible part is passed through intestines and discharged out of the anus (de Gaulejac, 1993) (Figure 4).

Species of fan mussels do not have a siphon mechanism but a pallial cavity instead, in which inhalant and exhalant chambers are completely separated by lamellibranch gills. In the absence of siphons, the mantle cavity and large posterior extension of the shell serve the function of siphonage (Butler et al., 1993). The species of $P$. nobilis keep its valves open as a gaping process in order to filter the water around it, which shows that an individual fan mussel has been in the process of feeding and respiration thanks to its wide-open valves. However, insufficiently gaped or completely closed valves imply that filtering has decelerated or ceased. The rate of filtration and valve gaping is determined by the existence of factors such as particle concentration, temperature, salinity, and stress (Gosling, 2003). Butler et al. (1993) reported that the species of $P$. nobilis can inhabit oligotypic environment, clean water and little resuspension of sediment. Sediment loading which harms gill cilia can affect activities of feeding and respiration (Katsanevakis, 2005; García-March et al., 2008; Coppa et al., 2010). Garcia-March et al. (2008) found that the gaping activity of $P$. nobilis is directly influenced by current intensity and direction rather than factors such as temperature, dissolved oxygen, turbidity, and chlorophyll- $a$. The gaping activity of the population is usually synchronous and a periodic cycle from 21.9 to $24 \mathrm{~h}$ of gaping activity occurs in all $P$. nobilis individuals during the year.

\section{Aquaculture}

Because species of fan mussels such as Pinna bicolor, Pinna rugosa, Atrina pectinata and Atrina maura are popularly consumed and marketed for high prices in Pacific and Asian countries (Cendejas et al., 1985), they are of commercially great potential. As a result, studies have been made on the aquaculture production of the species in order that its sustainable output should be obtained and natural stocks are protected.

As the species of $P$. nobilis has currently been under serious danger of extinction, in particular, the presence of aquaculture output, as well as control measures, is required in terms of protection of the species and regeneration of the stocks in the habitat. As a consequence of the diseases, stocks of $P$. nobilis have been on the brink of disappearance in most locations of the Mediterranean Sea. The fact that disease-free locations are determined where production is to be restarted requires the collection of spat from the environment and rearing larvae and thus juveniles.

\section{Reproduction and Maturation}

No studies have been encountered on determining the reproduction period of $P$. rudis and $A$. fragilis like $P$. nobilis. $P$. bicolor is gonochoristic (Roberts, 1984) whereas P. nobilis is of successively (alternately) hermaphrodite characteristic with its gonads developing through digestive organs. The color of gonads varies from light orange to dark brick hue, which is however not indicative of sexuality or any sexual phases (Figure 5) (Acarlı et al., 2018). Having matured, reproductive cells are 


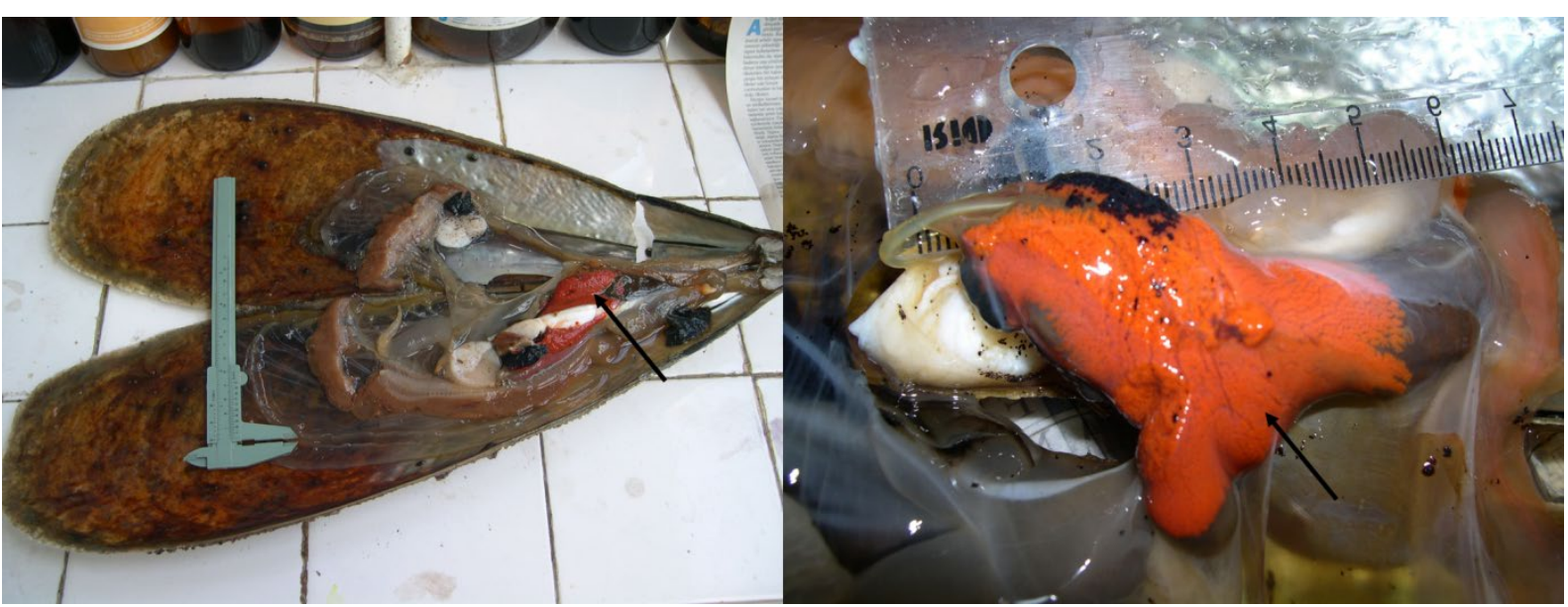

Figure 5. Gonadal appearance of Pinna nobilis (original)

water columns where the process of larval development is later completed (de Gaulejac, 1993). The reproductive cycle in fan mussels is influenced by endogenous factors such as energy reserves and genetic elements (Lee et al., 2015; Wang et al., 2017) and exogenous factors including variations in temperature, photoperiod and food quality and quantity (Baik, et al., 2001; Angel-Dapa et al., 2015; Qui et al., 2014; GongoraGomez et al., 2016a). Reproductive periods of $P$. nobilis in different regions are presented in Table 1 . Histological studies show that the reproductive period of $P$. nobilis occurs when the temperature has been high. $P$. nobilis can be cited to be a summer breeder species according to the classification by Boolotian et al. (1962) considering spawning in terms of comparison of spawning periods (Table 1). These differences may occur due to depth, thermocline position, degrees of latitudes and other regionals (Hernandis et al., 2018).

Table 1. Spawning periods of Pinna nobilis in different regions

\begin{tabular}{lll}
\hline Locality & Spawning period & References \\
\hline France & June-August $\left(26^{\circ} \mathrm{C}\right)$ & de Gaulejac (1995) \\
Spain & May-August $\left(20-26^{\circ} \mathrm{C}\right)$ & Deudero et al. (2017) \\
Turkey & May-September $\left(24-26^{\circ} \mathrm{C}\right)$ & Acarli et al. (2018) \\
\hline
\end{tabular}

As for the collection of sexually mature individuals, it is necessary to choose periods when condition index is high and muscle index low (Acarli et al., 2015; Angel-Dapa et al., 2015; Acarli et al., 2018). Maeno et al. (2009) and Chung et al. (2006) reported that the maturation progress of fan mussel broodstocks in suspension culture resembled that of those in natural beds. Angel-Dapa et al. (2015) informed that gamete quality, in other words, broodstock condition and origin (depth, phases of tidal cycle), as well as environmental conditions, could have effects on larval survival and growth rates in the studies of larval production. Species of microalgae such as Pavlova sp. and Chroococcus sp. have been found to be effective nutrient sources on the maturation of adult individuals. 18: $1 \mathrm{n}-9$ content is related to condition index and gonad index and can be used as the degree of maturation for gonads in them (Qiu et al., 2014). To enable the species under protection to sustain, rearing processes should be carried out. The first stage is therefore to determine the period of reproduction.

\section{Production of Larva}

When spawning has occurred, external fertilization of sperm and egg takes place and larval development from trochophore to pediveliger phase is planktonic with eventual settlement and metamorphosis (de Gaulejac \& Vicente, 1990). Mature fan mussel individuals collected from nature are exposed to temperature shock (Angel-Dapa et al., 2015; Trigos et al., 2018), hydrogen peroxidation (McCoy \& Chongpeepien, 1988) or UV (Yang et al., 2006) to obtain their gonadal cells.

The eggs having been incubated, larvae are fed on phytoplankton species of Isochrysis galbana, Tetraselmis sp., Chaetoceros calcitrans, Pavlova lutheri in such a way to be 5000 cells/ml for about 5-6 weeks to continue until the juvenile phases (Kawahara et al., 2004). However, the length of the larval period could vary according to the species, larva and mature quality and food (Gosling, 2003). Ohashi et al. (2008) were the first to successfully study the process of growing larvae and juveniles of $A$. pectinata in indoor tanks, though the study showed that the rate of survival was not desirable upon fertilization, hatching and attachment. During the latter, the rate of survival and length of spats were $0.004 \%$ and $514.1 \pm 25.9$ $\mu \mathrm{m}$, respectively.

Most of the studies on $P$. nobilis include those on population. Although a limited number of studies have been made involving juvenile production and growth, the first larval 
output process was performed by Trigos et al (2018), which involve the process from egg fertilization to pediveliger stage and tried different rearing tanks, larvae density, light conditions and food of amounts to determine the optimal condition for larval development. The results showed that $16 \mathrm{~L}$ tanks with a concentration of 2 larvae $\mathrm{ml}, 21^{\circ} \mathrm{C}$ constant temperature, 12/12 $\mathrm{h}$ photoperiod and feeding on an optimal mixture of 25 cells per $\mu \mathrm{L}$ of Chaetoceros calcitrans +33.3 cells per $\mu \mathrm{L}$ of Pavlova lutheri +100 cells per $\mu \mathrm{L}$ of Isochrysis galbana seem to be the best conditions to rear $P$. nobilis larvae. The larva achieved the stage of pediveliger in 7 days with a length of $110 \mu \mathrm{m}$. However, it failed to metamorphose by the end of 22 days. The problem seems to be that Vibrio is suspected to have caused mortalities over $80 \%$ during the first 2-9 days based on light conditions and food doses. The process of larval culture exhibited low survival rates and it was thus interpreted that hydrophobicity of pediveliger larvae resulted in their buoyancy on the water with eventual dehydration and/or starvation (Robles-Mungaray, 2004 as cited in Gómez Hernández, 2011) (Maeda-Martínez, 2008; Angel Dapa, 2015). Pediveliger larva has a thin and fragile shell and gradually stores lipids with the result that it has a positive buoyancy prior to metamorphosis (Maeda-Martínez, 2008). Successful completion of the larval stage with the metamorphosis of $P$. nobilis can only come true due to the formation and development of the culture hatchery protocol (temperature, salinity, density, feeding strategies, tank cleaning, water change, etc.).

\section{Spat Collection}

First young individuals obtained after the larval period are called spats with transparent shells and interior organelles visible to the naked eye (Figure 6). Yielding of spat collection is affected by environmental factors such as temperature, currents, water depth and type of collector material in particular (Narváez et al., 2000; Saucedo et al., 2005; Yıldız et al., 2005; Yildiz et al., 2013; Halla et al., 2018). A variety of natural and artificial collectors are used to obtain bivalve spats, including monofilament gillnets, PVC glass, onion bag, netlon, bivalve cultch (oyster, mussel, cardium, etc.), wood, fiberglass, car tires and tiles (Lök \& Yolkolu, 1999; Helm \& Bourne, 2004; Buitrago \& Avarado, 2005; Velasco \& Barros, 2010; Soria et al., 2015; Gregori et al., 2019). Although numerous collector designs and materials have been thus far tested, the productivity of a collector generally vary based on the species, the region and the duration of soaking the collector. Of such collectors, the most efficient are nylon filaments or onion bags made of polyethylene mesh for collecting fan mussels (Cendejas et al., 1985; Beer \& Southgate, 2006: Kersting \& Hendriks, 2019). The time of planting collector is generally important. Once it has been planted before reproduction, unwanted or untargeted species attached to the surface of the collector and the area to which species could attach would thus decrease. However, when it has been planted upon spawning period, its efficiency lowers then the rate of collecting target species drops as well (Lök \& Acarli, 2006; Yıldız et al., 2010; Yiğitkurt et al., 2017). The most available period for $P$. nobilis to attach is the summer months when temperature and presence of nutrients are high (Acarli et al., 2011a; Theodorou et al., 2015). On the other hand, the rate of attachment close to the water surface was found to be much better than in the depth of $8 \mathrm{~m}$ (Kurtay et al., 2018). Therefore, pelagic bivalve larvae tend to swim up to surface water where food concentration is high (Bayne 1976). Bivalve larvae exhibit a negative phototropic behavior to attachment when they avoid light and prefer sheltered substrates in shadow areas (Baker, 1997; Saucedo et al., 2005; Lök \& Acarli, 2006). In this context, Acarli et al. (2011a) observed that the spat settlement of $P$. nobilis was significantly higher within mesh collectors (92\%) than their exterior.

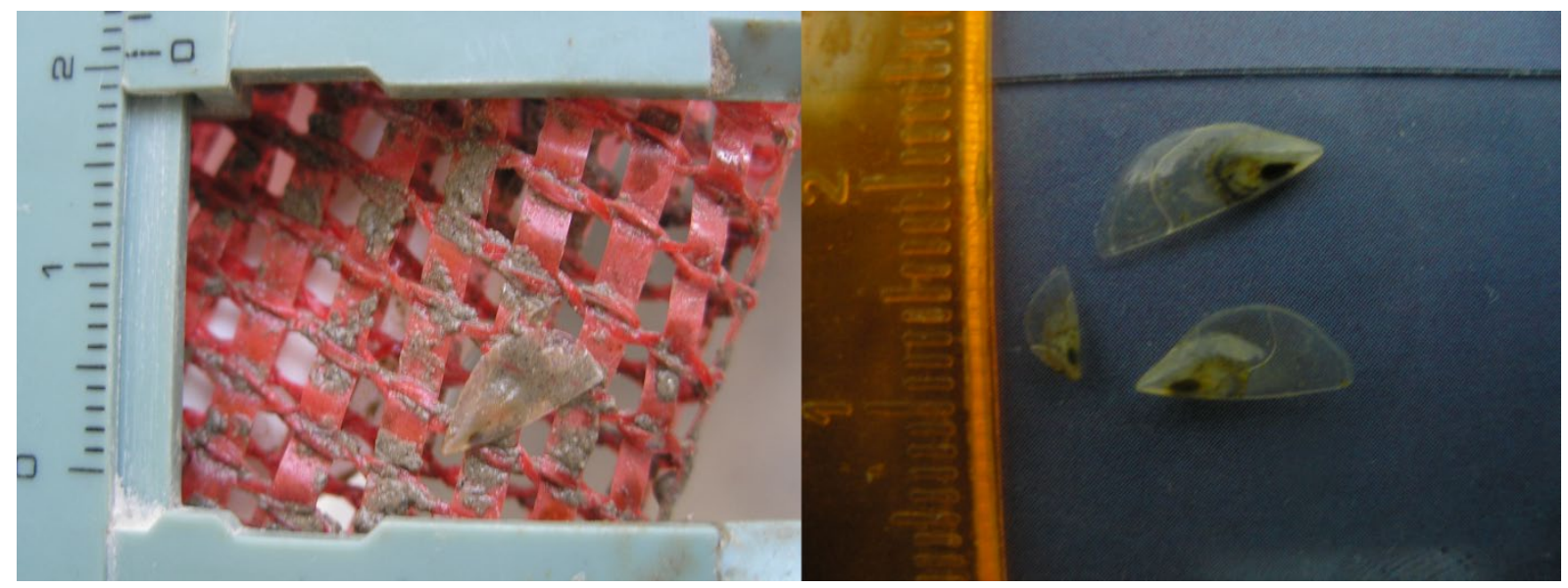

Figure 6. $P$. nobilis spat collection trials (Acarli et al., 2011a) 


\section{Culture Study}

All other species of the Pinnidae family including $P$. nobilis and $P$. bicolor are those whose shells grow the fastest in all bivalve species (Richardson et al., 2004). The upper section of the shell in water grows faster than the lower part on the bottom. The ones to inhabit deep water show a slower growth but achieve greater length than those in shallow water (GarcíaMarch et al., 2007). The growth of the Pinnidae family is influenced by food quality and quantity (Safi et al., 2007; Acarli et al., 2011b), temperature (Leyva-Valencia et al., 2001), salinity, reproduction (Narváez et al., 2000), pollutants (Góngora-Gómez et al., 2015), age and shells size (Demirci \& Acarli, 2019). Of those, food supply and optimum temperature are considered to be the most important for bivalves without which sustainable growth is difficult or almost impossible. The relationship between shell length and the total weight of $P$. nobilis was described with the equation $\mathrm{W}=0.003 \mathrm{~L}^{3.6451}\left(\mathrm{r}^{2}=\right.$ 0.9625), the result of which revealed that there was a positive allometric growth between shell length and total weight $(P<0.05)$ (Acarli et al., 2011b).

The juveniles are observed to grow faster as in other bivalve species but growth shows a deceleration later on both in culture and in situ growth studies (Katsanavakis, 2007; Aucoin \& Himmelman, 2011; Demirci \& Acarli, 2019). The rearing studies are generally based on the principle that the cultivation of juvenile individuals obtained from natural environments should be performed on suitable grounds. Culture trials and choice of system and field involve important criteria such as growth, mortality, meat yield, condition factor and biochemical composition of fan mussels (Arizpe, 1995). The process involves that the techniques of suspended culture and bottom culture are employed considering the area where individuals would be placed in the water column.

\section{Suspension Culture}

The purpose of the floating (long line or float raft) is to increase the amount of yield by means of excessive water volume and get rid of the pressure of predation present on the bottom as well, for which juveniles are placed in the materials such as boxes, tray pearl baskets, lantern nets, etc. hung down from the system above. On their bottom is placed sufficient amounts of sand into which fan mussels could be buried and planted (Wu \& Shin, 1998) or instead rearing process can be performed without placing sand in the same materials cited above (Acarli et al., 2011b) (Figure 7). Values of shell width, dry tissue weight and condition index for $P$. bicolor juveniles (30-40 $\mathrm{mm}$ shell width) in raft culture were found to be higher than those on the sea bottom (Wu \& Shin, 1998). Koźul et al. (2011) reported that $P$. nobilis grew very rapidly and reached from 29 $\mathrm{mm}$ to $157 \mathrm{~mm}$ over a year. Kozul et al. (2013) also placed the cages with juveniles at three depths: $1 \mathrm{~m}, 3 \mathrm{~m}$ and $5 \mathrm{~m}$ to finally see that following the two-year growth period the average length was $244 \pm 22.9 \mathrm{~mm}$ at $1 \mathrm{~m}$, the specimens averaged $244 \pm 25.3 \mathrm{~mm}$ at $3 \mathrm{~m}$ and the average length was $231.1 \pm 22.5 \mathrm{~mm}$ at $5 \mathrm{~m}$. The rearing processes within cages managed to solve some problems primarily caused by human activities for purpose of improving natural fan mussel populations. Beer \& Sauthagate (2006) placed $P$. bicolor species in pocket panel nets to find that they grew from $75.5 \pm 1.19 \mathrm{~mm}$ to $175.5 \pm 3.9 \mathrm{~mm}$ in hinge length by the end of an 80 -week period when the deceleration of the growth was associated with the reproduction activity. There was a positive effect of the suspended culture system and pocket panel nets on survival with a $78 \%$ rate at the end of the study. Because the suspended system generally makes it possible to work at a given distance from the ground, the pressure of predators on juveniles decreases while the rate of survival increases (Wu \& Shin, 1998; Leal-Soto et al., 2011).

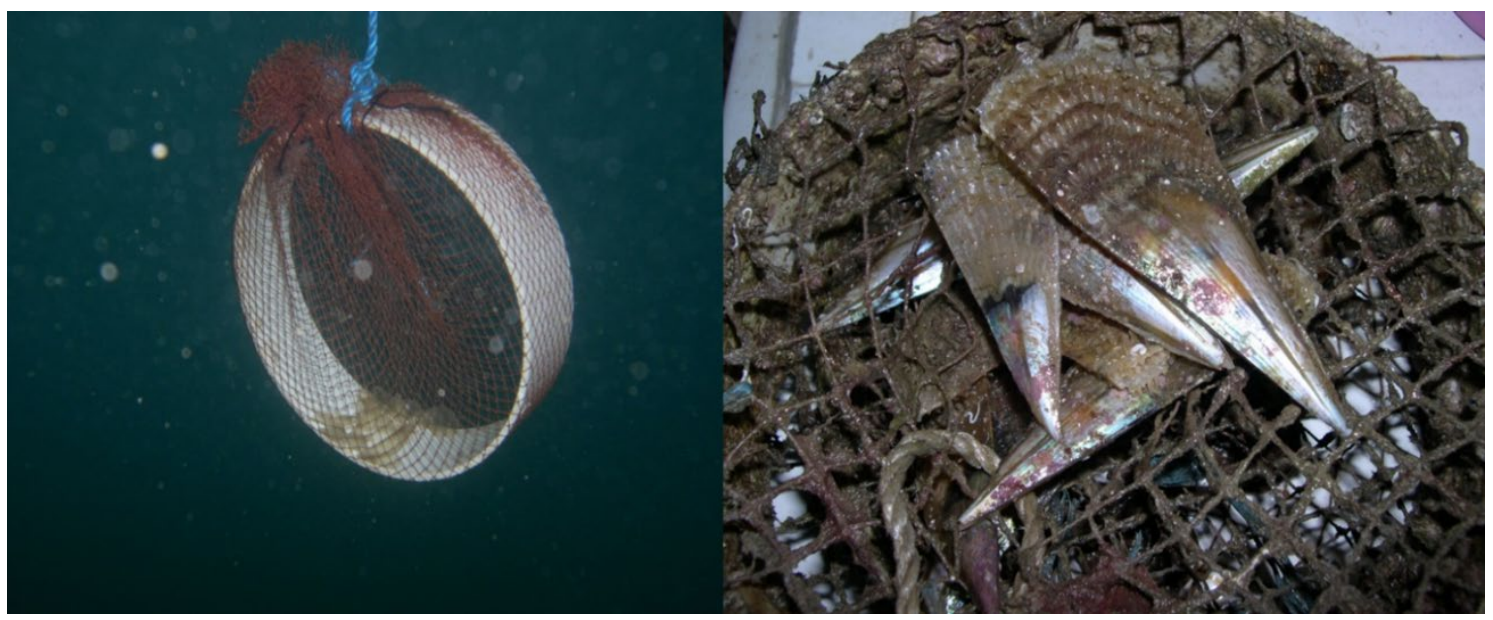

Figure 7. Suspension culture trials of $P$. nobilis (Acarli et al., 2011b) 
Having collected P. carnea individuals, Velasco \& Borrero (2004) stocked them at two different concentrations of $10 \%$ and $20 \%$ in pearl oyster rearing nets and left them in a $9 \mathrm{~m}$ depth. By the end of the study, the ones of $10 \%$ and those of $20 \%$ concentrations grew to $167.5 \mathrm{~mm}$ and to $156.5 \mathrm{~mm}$, respectively. There were no differences in survival rates between the two groups. Unlike other studies, early in the study, predator pressure (Cymattidae, Majidae, Portunidae and Xantidae) was cited and mortalities were encountered due to predation pressure as well as environmental factors. A suspended culture system requires basically higher investment in facilities, sophisticated equipment and labor force, which is of greater cost and thus supposed to be regularly controlled (Leal-Soto et al., 2011).

\section{Bottom Culture}

Post-settlement and juvenile mortality in benthic invertebrates are high because of predation (Aucoin \& Himnelman, 2011). The ability to perform protected and unprotected systems on the bottom-related cultures is based on the availability of the predator population. The posterior portion of fan mussel species vertically rises over the bottom surface whereas its anterior part is buried into the bottom sediment, which could cause exposure to predators (fish, octopus, crabs, muricid, gastropods, etc.) (Yonge, 1953). Juveniles have relatively thin shells. If there is too much presence of predators likely to harm juveniles in the environment, they should be protected against predation. Kersting \& Garcia-March (2017) reported that plastic framecasing of individuals could result in the reduction of influences of currents and pressure of predators. After fan mussels have been planted into the bottom in the protected systems, net cages of suitable mesh size are placed to cover over in order to prevent predators from reaching there. Unprotected systems just involve the young to be planted into predetermined rearing spots without any protective cages.

A. maura were cultured in the sand bottom of 36 fan mussels $/ \mathrm{m}^{2}$ each in Ensenada Pabellones lagoon system $(<10 \mathrm{~m}$ deep), Mexico, about which any protective systems were not cited at all. A one-year-culture study showed that the rate of survival was $91.66 \%$ with the shell length growing from $28.41 \pm 4.69 \mathrm{~mm}$ to $218.16 \pm 12.41 \mathrm{~mm}$. The study also indicates that the presence of predators in the water column affects the survival rate. In this sense, it is important to choose the area in rearing trials as well. Some authors pointed out that the bottom culture of bivalves had lower growth rates and higher predation loss than the suspended culture Emerson et al., 1994; Barbeau et al., 1996; Lodeiros et al., 2002). However, the pressure of predators can be decreased by choosing an available region or some means to be used for protection. In this sense, it is important to choose the area in rearing trials as well. Some authors pointed out that the bottom culture of bivalves had lower growth rates and higher predation loss than the suspended culture (Emerson et al., 1994; Barbeau et al., 1996; Lodeiros et al., 2002). However, the pressure of predators can be decreased by choosing an available region or some means to be used for protection.

\section{Suspended and Bottom Cultures}

Studies on the combination of suspended and bottom cultures for fan mussels to be reared were reported by MirandaBaeza (1995), and Cardoza-Velasco \& Maeda-Martinez (1997). In addition, Leal-Soto et al. (2011) cultured A. maura juveniles by combining both production systems. The individuals were first placed into plastic trays covered over with $2 \mathrm{~mm}$ plastic mesh and suspended by long line systems. Shell lengths of 1300 juveniles were $15 \pm 5 \mathrm{~mm}$ early in the trial and kept in the system until they grew to a mean of $32.8 \pm 6.7 \mathrm{~mm}$ for two months. The survival rate in long line system was $90 \%$. The juveniles were later placed on a location of $20 \mathrm{~m}^{2}$ present in $4 \mathrm{~m}$ depth $100 \mathrm{~m}$ off the shore. Prior to the trial, the site bottom was cleared of rocks, pebbles and mosses. 140 individuals $/ \mathrm{m}^{2}$ were manually buried into the bottom and covered over by the cages of $2 \times 1.5 \times 0.2 \mathrm{~m}$ framed by a 0.5 -inch construction steel bar. The cages were covered with a plastic net of $8 \mathrm{~mm}$ mesh. The process of ground rearing was continued for 20 months with a mean shell length of $194.6 \pm 10.2 \mathrm{~mm}$ and a $70 \%$ survival rate.

Góngora-Gómez et al. (2016b) conducted an experimental study similar to the A. maura process, combining suspended and bottom cultures in Isla Los Redos in the southeast of California Gulf, Mexico for 15 months (February 2008-May 2009). Young individuals $(n=2500)$ were subjected to the suspended culture and their mean shell height and total weight varied from $16.20 \pm 4.96 \mathrm{~mm}$-and $0.3 \pm 0.2 \mathrm{~g}$ to $119.66 \pm 8.98 \mathrm{~mm}$ and $38.68 \pm 10.34 \mathrm{~g}$, respectively. The survival rate was found to be $97 \%$. They were then planted into sand bottom within the area surrounded by the protective cover framed with corral or fence and preserved until the harvest process for 11 months with a mean shell height of $220.48 \pm 12.41 \mathrm{~mm}$, the total weight of $284.26 \pm 54.45 \mathrm{~g}$ and a survival rate of $88.72 \%$.

$P$. nobilis individuals reared by the suspended system were buried into the bottom of $3 \mathrm{~m}$ depth bottom around Karantina Island, Urla, Izmir in April 2008. Their total height (anteriorposterior) ranged from $125 \mathrm{~mm}$ to $185 \mathrm{~mm}$. The survival rate 
was 100\% after 6 months and 1 year (Figure 8) (Unpublished study of the author).

The reason for the combination of the two culture systems is that the survival rate is low based on the fragility of the newly settled individuals. However, their fragility decreases when they have achieved $100 \mathrm{~mm}$ length. In other words, the higher the size, the more resistance to predators would be (Velasco \& Borrero, 2004). Moreover, juveniles less than $30 \mathrm{~mm}$ buried into the bottom could be uprooted by currents and/or easily killed by predators (Leal- Soto et al., 2011). It is generally an important parameter to often clean culture cages used in the suspended process and manually keep predators off in the water in terms of increasing rates of growth and survival. Grown individuals should be vertically buried into the lower layer to maximize their process of nourishment, which is better than suspended culture. Thanks to the above, they could adjust themselves to the process until they have been adults and function their reproduction activity healthily. It seems more appropriate to assess both culture systems in combination for $P$. nobilis to avoid risking any stages of development due to the security of accurate control over the process with minimum mortality in the process.

\section{Transplantation}

Transplantation is the method used to sustain and increase the production of endangered or threatened species of commercially valuable species under danger of extinction. The process has been usually performed for bivalve species such as Crassostrea virginica (Powell et al., 1997), European oyster Ostrea edulis (Çelik et al., 2013) and Gastropod species such as limpet Patella ferruginea (Espinosa et al., 2008), green abalone Haliotis fulgens (Guzman Del Proo et al., 2004). The conducted activity has also been used for fan mussels such as Atrina maura (Mendo et al., 2011), Pinna bicolor (Wu \& Shin, 1998) and Pinna rugosa (Arizpe, 1995) which are of commercial importance and targeted to be cultivated. Achievement of the transplantation process can generally be affected by anthropogenic factors, stock density, size of individuals to be planted, the pressure of predation and environmental parameters (temperature, salinity, sediment structure, nutrient quality and quantity, and currents).

P. nobilis continues to decline where it inhabits. Therefore, transplantation could be performed as one of the remedies for the generation of $P$. nobilis to sustain, for which the first transplantation trial was conducted in the Adriatic Sea by

Table 2. Transplantation studies for $P$. nobilis

\begin{tabular}{|c|c|c|c|c|}
\hline Location & Survival rate $(\%)$ & $\mathbf{N}$ & Depth (m) & Reference \\
\hline North Eastern Coast of Sardinia & 75 & 18 & & Caronni et al. (2007) \\
\hline Lake Vouliagmeni (Korinthiakos Gulf, Greece) & 95.6 & $45(11-16 \mathrm{~cm})$ & 12 & Katsanevakis (2016) \\
\hline
\end{tabular}

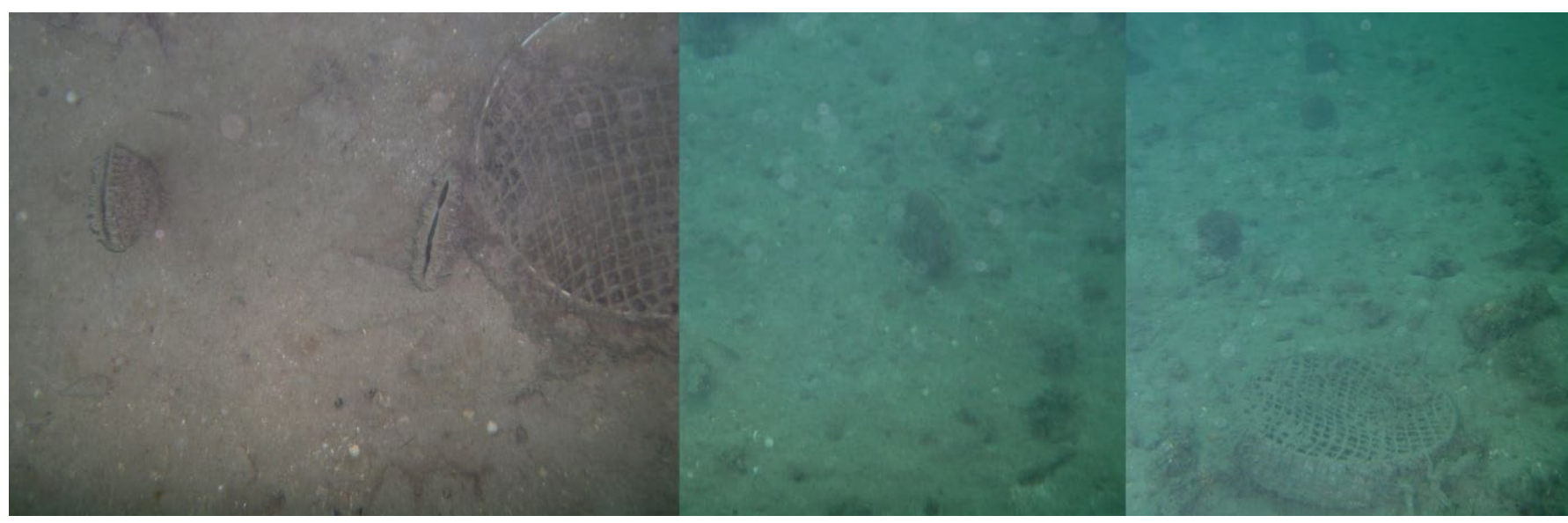

Figure 8. Individuals planted into bottom after rearing trial in the Karantina Island (İzmir Bay, Aegean Sea) in December 2006 


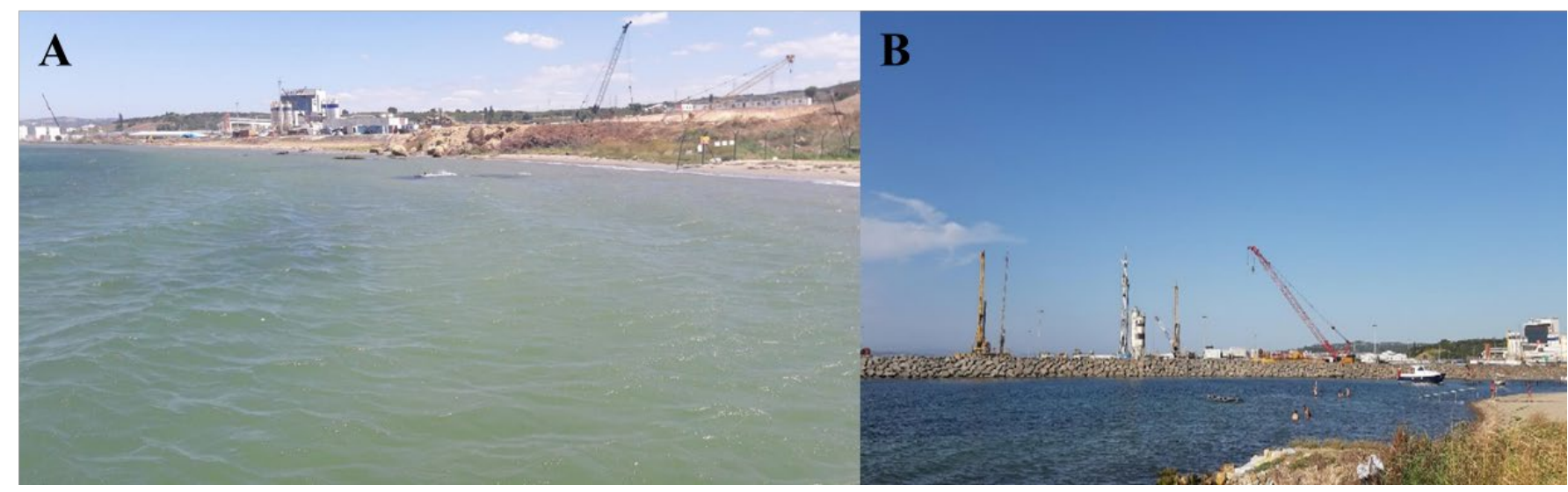

Figure 9. The location where P. nobilis collected from the Çanakkale Strait. Before (A) and after (B) the construction of the 1915 Çanakkale Bridge

Mihailinović (1955) for commercial purposes such as growing to market its shell, meat and byssus (Mihailinović, 1955 as cited in Trigos \& Vicente, 2016), followed by the fact that Vicente et al. (1980), Hignette (1983). de Gaulejac \& Vicente (1990) designed transplantation processes and performed small scale experiments. The importance of transplantation processes has further increased in the consequence of intense mortalities of $P$. nobilis species in several sections of the Mediterranean Sea (Table 2), which is therefore of additional emphasis for the rehabilitation of affected stocks. The related process is of additional importance in determining, monitoring and protecting surviving individuals in infected populations in order to pave the way for the studies to be made later. In other words, strong individuals are necessary to be able to survive. It would be a crucial issue to transplant generations that could be obtained from individuals able to survive and thus become resistant to diseases in natural and culture-based conditions where they could be rehabilitated and cultured in terms of their sustainability.

\section{Transplantation Studies in Turkey}

Present in the area of construction of 1915 Çanakkale Bridge was started in 2018 between the European and Asian sides of the Çanakkale Strait, live transportation of $P$. nobilis population was transported to a secure location (Figure 9) 14 P. nobilis individuals were found to exist in the construction of the European side of the strait and carried to the area $500 \mathrm{~m}$ away from where they would eventually be buried into a $1-1.5 \mathrm{~m}$ depth of the sea bed. 1040 individuals from the construction on the Asian side were transplanted to the area 300-350 $\mathrm{m}$ afar into which to bury them 4-4.5 $\mathrm{m}$ depth. Two months after the transplantation, submarine observation indicated $1 \%$ mortality. One year later, however, $P$. nobilis population was seen to be healthy with good adaptation to the transplantation site. Observatory scuba diving performed in 2020 showed high rates of mortality where transplantation was performed as well as in other sections of the strait. The fact that young individuals in the transplantation area on the Asian side are those estimated to be within the age range of 1-1.5 showed that the population completed the process of adaptation with the managed stress and resultant reproduction activity. However, the area may be currently exposed to the influence of the disease $H$. pinnae.

\section{Recommendations for the Transplantation Operation of $P$.} nobilis

The parameters to be considered during the transplantation can be listed as below;

- Depths, water conditions, individual density and sediment structure of the areas where fan mussels are distributed are to be taken into account.

- "Specific Protection Areas" have to be constituted in transplantation sites with the exception of those where fisheries activities are forbidden and anthropogenic factors are negligible,

- "Specific Sheltered Area" is supposed to be designed to decrease or eliminate the pressure of predation similar to Subaquatic Park Systems during the studies of rehabilitation,

- Caution and care should be exerted lest byssal threads could be broken off while removing $P$. nobilis individuals off the sea bed.

- Individuals ripped off the bottom should be carried without being shaken in seawater to the transplantation area,

- Individuals should be planted as vertically as possible in the plantation process.

- Individuals should be planted considering the previous depth traces of mud and sand or unburned depth. 


\section{Conclusion and Recommendations}

P. nobilis and P. rudis were used as human consumption for meat and their shells and byssal threads for decorative purposes until 1992 and 1996, respectively. However, due to overfishing and the destruction of their habitats, their populations have been recorded to be significantly reduced. Considering the damage to the population of $P$. nobilis, the status of the species was established to be at critical levels. Accordingly, new plans of action should be constituted in terms of its sustainability.

By determining active disease agents (Mycobacterium spp. and $H$. pinnae), the interaction between pathogenesis and epizootiology namely, between host, parasite and environment should be explained, which is thus vital in determining methods to be followed for regeneration of the stocks and preventing diseases from spreading.

The rapid flow of information could be provided thanks to the formation of a network system involving local administrations, people, diving clubs and commercial and sportive fishermen along marine regions in terms of mapping distribution of $P$. nobilis. Following the establishment of healthy populations, in particular, the constituents within the network system above should be allowed to assume missions on information, protection and control. Therefore, a program of protecting and rehabilitating $P$. nobilis could be instituted within such an integrated system.

Surveys of field scanning helped to record masses of mortalities in most regions from Western Mediterranean shores to Aegean Sea. Similarly, a $100 \%$ rate of mortality was seen at the Aegean mouth of the strait whereas the entrance of the Marmara Sea exhibited a 9.2\% rate of mortality, where there have yet to be any cases of the diseases. The disease-stricken populations are assumed to need a long time to recover, that is, the ability of resistant individuals to function in reproduction activity. It is therefore of great importance to determine, monitor and protect such populations in view of sustainability.

It is to be aimed those spats to be picked up by collectors from healthy populations in the Marmara Sea should be exposed to rearing and planting into new sediments when they have become $15 \mathrm{~cm}$ in length and thus forming new populations. However, it is quite necessary to keep the area of the newly planted individuals under protection and follow them up in terms of constituting the new population. Reviving mostly or completely damaged populations by replanting processes should be applied as a mere solution.

Knowledge of the reproductive biology of the species is very important. Development of programs for adult maturation is needed. What reduces the survival rate of larva, in particular, is its high hydrophobicity, to put clearly, its sticking onto water surface and walls of the tanks, which requires an emphasis on specific techniques. It seems very important that individuals preserved in the incubator under culture conditions until the phase of spats should be taken to progressive sheltered culture systems and reared on the surface and the bottom in terms of regeneration.

The related references should be taken into consideration in prospective research concerning the studies aimed at understanding comparative evolution, comparative genomics or genetic variation of $P$. nobilis to develop effective protective plans of the genome.

\section{Compliance With Ethical Standards}

\section{Conflict of Interest}

The author declares that there is no conflict of interest.

\section{Ethical Approval}

For this type of study, formal consent is not required.

\section{References}

Acarli, D., Acarli, S., \& Öktener, A. (2020). Mass mortality report of critically endangered fan mussel (Pinna nobilis, Linnaeus 1758) from Cunda Island, Ayvalık (Aegean Sea, Turkey). Acta Natura et Scientia, 1(1), 109 117. https://doi.org/10.29329/actanatsci.2020.313.12

Acarli, S., Acarli, D., \& Kale, S. (2021a). Current status of critically endangered fan mussel Pinna nobilis (Linnaeus 1758) population in Çanakkale Strait, Turkey. Marine Science and Technology Bulletin, 10(1), 62-70. https://doi.org/110.33714/masteb.793885

Acarli, D., Acarli, S., \& Kale, S. (2021b). The effects of mucilage event on the population of critically endangered Pinna nobilis (Linnaeus 1758) in Ocaklar Bay (Marmara Sea, Turkey). Acta Natura et Scientia, 2(2), 148-158. https://doi.org/10.29329/actanatsci.2021.350.09

Acarli, S., Lok, A., Yigitkurt, S., \& Palaz, M. (2011a). Culture of fan mussel (Pinna nobilis, Linnaeus 1758) in relation to size on suspended culture system in Izmir Bay, Aegean Sea, Turkey. Kafkas Universitesi Veteriner Fakültesi Dergisi, 17(6), 995-1002. 
Acarli, S., Lök, A., \& Acarli, D. (2011b). Preliminary spat settlement of fan mussel Pinna nobilis Linnaeus 1758 on a mesh bag collector in Karantina Island (Eastern Aegean Sea, Turkey). Fresenius Environmental Bulletin 20(10), 2501-2507.

Acarli, S., Lök, A., Acarli, D., \& Kırtık, A. (2018). Reproductive cycle and biochemical composition in the adductor muscle of the endangered species fan mussel (Pinna nobilis, Linnaeus 1758) from the Aegean Sea. Turkey. Fresenius Environmental Bulletin, 27(10), 6506-6518.

Acarli, S., Lök, A., Acarli, D., Serdar, S., Küçükdermenci, A., Yiğitkurt, S., Kırtık, A., \& Güler, M. (2010). Urla karantina adası civarında dă̆ılım gösteren pina (Pinna nobilis, Linnaeus 1758) kabukları üzerine tutunan makrobentik türler. Türkiye'nin Kıyı ve Deniz Alanları VIII. Ulusal Konferansı, Turkey. pp. 741-746.

Acarli, S., Lök, A., Kirtik, A., Acarli, D., Serdar, S., Kucukdermenci, A., Yigitkurt, S., Yildiz, H., \& Saltan, A. N. (2015). Seasonal variation in reproductive activity and biochemical composition of flat oyster (Ostrea edulis) in the Homa Lagoon, Izmir Bay, Turkey. Scientia Marina, 79(4), 487-495. https://doi.org/10.3989/scimar.04202.16A

Acarli, S., Vural, P., \& Öktener, A. (2019). Association between the crab, Nepinnotheres pinnotheres (Linnaeus, 1758), and the endangered species fan mussel, Pinna nobilis (Linnaeus, 1758), from the Aegean Sea, Turkey. Alinteri Journal of Agriculture Sciences, 34(2), 169-174. https://doi.org/10.28955/alinterizbd.639029

Addis, P., Secci, M., Brundu, G., Manunza, A., Corrias, S., \& Cau, A. (2009). Density, size structure, shell orientation and epibiontic colonization of the fan mussel Pinna nobilis L. 1758 (Mollusca: Bivalvia) in three contrasting habitats in an estuarine area of Sardinia (W Mediterranean). Scientia Marina, 73(1), 143-152. https://doi.org/10.3989/scimar.2009.73n1143

Aktan, Y., Dede, A., \& Çiftçi Türetken, P. S. (2008). Mucilage event associated with diatoms and dinoflagellates in Sea of Marmara, Turkey. Harmful Algae News: An IOC Newsletter on Toxic Algae and Algal Blooms, 36, 1-3.

Angel-Dapa, M. A. (2015). Evaluación De La Dinámica Energética Y El Desempeño Reproductivo Y Larvario Del Callo De Hacha Atrina maura (Bivalvia: Pinnidae). [Ph.D. Thesis, Instituto Politécnico Nacional] (In Spanish).
Angel-Dapa, M. A., Arellano-Martínez, M., Ceballos-Vásquez, B. P., Robles-Mungaray, M., Robles-Rocha, E., Camacho-Mondragón, M. A., \& Saucedo, P. E. (2015). Reproductive and larval performance of the pen shell Atrina maura in relation to the origin and condition of broodstock. Journal of Shellfish Research, 34(2), 401-408. https://doi.org/10.2983/035.034.0223

Arizpe, C. O. (1995). Mortality, growth and somatic secondary production of the bivalve, Pinna rugosa (sowerby), in suspended and bottom culture in Bahia de La Paz, Mexico. Aquaculture Research, 26(11), 843-853. https://doi.org/10.1111/j.1365-2109.1995.tb00878.x

Aucoin, S., \& Himmelman, J. H. (2011). Factors determining the abundance, distribution and population sizestructure of the pen shell Pinna carnea. Journal of the Marine Biological Association of UK, 91(3), 593-606. https://doi.org/10.1017/S0025315410001360

Baik, S. H., Kim, K. J., Choo, J. J., \& Park, K. H. (2001). Seasonal variations in biochemical components of the visceral mass and adductor muscle in the pen shell, Atrina pectinanta. Journal of Fisheries Science and Technology, 4(1), 18-24.

Baker, P. (1997). Settlement site selection by oyster larvae, Crassostrea virginica: Evidence for geotaxis. Journal of Shellfish Research, 16(1), 125-128.

Balkis-Ozdelice, N., Durmuş, T., \& Balci, M., (2021). A preliminary study on the intense pelagic and benthic mucilage phenomenon observed in the Sea of Marmara. International Journal of Environment and Geoinformatics, $\quad 8(4), \quad 414-422$. https://doi.org/10.30897/ijegeo.954787

Barbeau, M. A., Hatcher, B. G., Scheibling, R. E., Hennigar, A. W., Taylor, L. H., \& Risk, A. C. (1996). Dynamics of juvenile sea scallop (Placopecten magellanicus) and their predators in bottom seeding trials in Lunenburg Bay, Nova Scotia. Canadian Journal of Fisheries and Aquatic Sciences 53, 2494-2512. https://doi.org/10.1139/f96-202

Basso, L., Vázquez-Luis, M., García-March, J. R., Deudero, S., Alvarez, E., Vicente, N., Duarte, I. E., \& Hendriks, I. E. (2015). The pen shell, Pinna nobilis: A review of population status and recommended research priorities in the Mediterranean Sea. Advances in Marine Biology, 71, 109-160. https://doi.org/10.1016/bs.amb.2015.06.002

Bayne, B. L. (1976). Aspects of reproduction in bivalve molluscs. In Wiley, M. (Ed.), Estuarine processes: Use, 
stresses and adaptation to the estuary (pp. 432-448). Academic Press.

Becker, C., \& Türkay, M. (2017). Host specificity and feeding in European pea crabs (Brachyura, Pinnotheridae). Crustaceana, 90(7-10), 819-844. https://doi.org/10.1163/15685403-00003661

Beer, C., \& Southgate, P. C. (2006). Spat collection, growth and meat yield of Pinna bicolor (Gmelin) in suspended culture in northern Australia. Aquaculture, 258(1-4), 424-429. https://doi.org/10.1016/j.aquaculture.2006.04.014

Boolootian, R. A, Farmanfarmaian, A., \& Giese, A. C. (1962). On the reproductive cycle and breeding habits of two western species of Haliotis. The Biological Bulletin, 122(2), 183-193. https://doi.org/10.2307/1539587

Bottari, T., Spinelli, A., Busalacchi, B., Rinelli, P., \& Salvatore, G. (2017). Transplant trials of the fan mussel Pinna nobilis inside the coastal lagoon of Capo Peloro (Central Mediterranean, Italy). Journal of Shellfish Research, 36(1), 3-8.

Buitrago, E., \& Alvarado D. (2005). A highly efficient oyster spat collector made with recycled materials. Aquacultural Engineering, 33(1), 63-72. https://doi.org/10.1016/j.aquaeng.2004.11.003

Butler, A., Vicente, N., \& de Gaulejac, B. (1993). Ecology of the pterioid bivalves Pinna bicolor Gmelin and Pinna nobilis L. Marine Life, 3(1-2), 37-45.

Capó, X., Tejada, S., Box, A., Deudero, S., \& Sureda, A. (2015). Oxidative status assessment of the endemic bivalve Pinna nobilis affected by the oil spill from the sinking of the Don Pedro. Marine Environmental Research, 110, 19-24. https://doi.org/10.1016/j.marenvres.2015.07.013

Cardoza-Velasco, F., \& Maeda-Martínez, A. N. (1997). An approach to aquacultural production of the penshell, Atrina maura Sowerby, 1835 (Bivalvia: Pinnidae) in Northwest Mexico. Journal of Shellfish Research: Abstracts of Technical Papers Presented at the 89th Annual Meeting, 16(1), 311.

Carella, F., Aceto, S., F., Polloro, Miccio, A., Laria, C., Carassco, N., Prado, P., \& De Vico, G. (2019). A mycobacterial disease is associated with the silent mass mortality of the pen shell Pinna nobilis along the Tyrrhenian coastline of Italy. Scientific Reports, 9, 2725. https://doi.org/10.1038/s41598-018-37217-y

Caronni, S., Cristo, B., \& Torelli, A. (2007). Tentativi di reimpianto del mollusco bivalve Pinna nobilis (Linneo, 1758) in una AMP della Sardegna [Attempts to transplant the Bivalve Pinna nobilis (Linneo, 1758) in a Sardinian marine protected area]. Biologia Marina Mediterranea, 14(2), 98-99.

Catanese, G., Grau, A., Valencia, J. M., Garcia-March, J. R., Vázquez-Luis, M., Alvarez, E., Deudero, S., Darriba, S., Carballal, M. J., \& Villalba, A. (2018). Haplosporidium pinnae sp. nov., a haplosporidan parasite associated with mass mortalities of the fan mussel, Pinna nobilis, in the Western Mediterranean Sea. Journal of Invertebrate Pathology, 157, 9-24. https://doi.org/10.1016/j.jip.2018.07.006

Çelik, M. Y., Karayücel, S., Karayücel, İ., Eyüboğlu, B., \& Öztürk, R. (2013). The effects of environmental factors on survival, growth and biochemical composition of transplanted oysters. (Ostrea edulis Linnaeus, 1758) from Aegean Sea to southern Black Sea. Aquaculture Research, 46(4), 959-968 https://doi.org/10.1111/are.12253

Cendejas, J. M., Carvallo, M. G., \& Juarez, L. M. (1985). Experimental spat collection and early growth of the pen shell, Pinna rugosa (Pelecypoda: Pinnidae), from the Gulf of California. Aquaculture, 48(3-4), 331-336. https://doi.org/10.1016/0044-8486(85)90135-8

Chung, E. Y., Baik S. H., \& Ryu, D. K. (2006). Reproductive biology of the pen shell, Atrina (Servatrina) pectinata on the Boryeong coastal waters of Korea. Korean. Journal of Malacology, 22(2), 143-150.

Cinar, M. E., Bilecenoğlu, M., Yokeş, M. B., \& Güçlüsoy, H. (2021). The last fortress fell: mass mortality of Pinna nobilis in the Sea of Marmara. Mediterranean Marine Science, 22(3), 669-676. https://doi.org/10.12681/mms.27137

Coppa, S., Guala, G.A., De Lucia, G.A., Massaro, G., \& Bressan, M. (2010). Density and distribution patterns of the endangered species Pinna nobilis within a Posidonia oceanica meadow in the Gulf of Oristano (Italy). Journal of the Marine Biological Association of the United Kingdom, 90(5), 885-894. https://doi.org/10.1017/S002531540999141X

Coronel, J. S. (1981). Estudio gonadal de Pinna rugosa (Sowerby, 1835) Pinnidae, Mollusca, en el período comprendido entre agosto de 1979 y diciembre de 1980 en la Bahía de La Paz. [Ph.D. Thesis. Universidad Autónoma de Baja California Sur].

Czihak, G., \& Dierl, W. (1961). Pinna nobilis L.: eine Präparationsanleitung. G. Fischer. 
Darriba, S. (2017). First haplosporidan parasite reported infecting a member of the Superfamily Pinnoidea (Pinna nobilis) during a mortality event in Alicante (Spain, Western Mediterranean). Journal of Invertebrate Pathology, 148, 14-19. https://doi.org/10.1016/j.jip.2017.05.006

Davenport, J., Ezgeta-Balić, D., Peharda, M., Skejić, S., Ninčević-Gladan, Ž., \& Matijević, S. (2011). Sizedifferential feeding in Pinna nobilis L. (Mollusca: Bivalvia): Exploitation of detritus, phytoplankton and zooplankton. Estuarine, Coastal and Shelf Science, 92(2), 246-254. https://doi.org/10.1016/j.ecss.2010.12.033

De Gaulejac, B. (1993). Etude écophysiologique du mollusque bivalve méditerranéen Pinna nobilis L. reproduction; croissance; respiration. [Ph.D. Thesis. Université d'AixMarseille].

De Gaulejac, B., \& Vicente, N. (1990). Ecologie de P. nobilis (L.) mollusque bivalve sur les côtes de Corse. Essais de transplantation et expériences en milieu contrôlé. Haliotis, 20, 83-100.

De Gaulejac, B., Henry, M., \& Vicente, N. (1995). An ultrastructural study of gametogenesis of the marine bivalve Pinna nobilis (Linnaeus 1758) I. oogenesis. Journal of Molluscan Studies, 61(3), 375-392. https://doi.org/10.1093/mollus/61.3.375

Guzman Del Proo, S.A., Carillo-Laguna, J., Belmar-Perez, J., Carreon-Palau, L., \& Castro, A. (2004). Transplanting of wild and cultivated juveniles of green abalone (Haliotis fulgens Philippi 1845): growth and survival. Journal of Shellfish Research, 23(3), 855-861.

Demirci, A., \& Acarl1, S. (2019). Estimation growth parameters of endangered the fan mussel species (Pinna nobilis L.) by using different growth models from Izmir Bay, Aegean Sea, Turkey. Fresenius Environmental Bulletin, 28(10), 7368-7374.

Deudero, S., Grau, A., Vázquez-Luis, M., Álvarez, E., Alomar, C., \& Hendriks, I. (2017). Reproductive investment of the pen shell Pinna nobilis Linnaeus, 1758 in Cabrera National Park (Spain). Mediterranean Marine Science, 18(2), 271-284. https://doi.org/10.12681/mms.1645

Deudero, S., Vázquez-Luis, M. \& Álvarez, E. (2015). Human stressors are driving coastal benthic long-lived sessile fan mussel Pinna nobilis population structure more than environmental stressors. PLoS ONE, 10(7), e0134530. https://doi.org/10.1371/journal.pone.0134530
Emerson, C. W., Grant, J., Mallet, A., \& Carver, C. (1994). Growth and survival of sea scallops Placopecten magelleanicus: effects of culture depth. Marine Ecology Progress Series, 108(1-2), 119-132. https://doi.org/10.3354/meps108119

Escamilla-Montes, R., Diarte-Plata, G., Luna-González, A., Fierro-Coronado, J. A., Esparza-Leal, H. M., GranadosAlcantar, S., \& Ruiz-Verdugo, C. A. (2017). Ecology, fishery and aquaculture in Gulf of California, Mexico: pen shell Atrina maura (Sowerby, 1835). In: Ray, S. (Ed.), Organismal and Molecular Malacology. InTech Open.

Espinosa, F., González, A. R., Maestre, M. J., Fa, D. A., GuerraGarcía, J. M., \& García-Gómez, J. C. (2008). Responses of the endangered limpet Patella ferruginea to reintroduction under different environmental conditions: survival, growth rates and life-history, Italian Journal of Zoology, 75(4), 371-384. https://doi.org/10.1080/11250000801887740

Fischer, W., Bauchot, M. L., \& Schneider, M. (1987). Fiches FAO d'identification des espèces pour les besoins de la pêche. (Revision 1). Méditerranée et mer Noire. Zone de pêche 37. Volume I. Végëtaux et Invertébrés. Rome, FAO.

Flander-Putrle, V., \& Malej, A. (2008). The evolution and phytoplankton composition of mucilaginous aggregates in the northern Adriatic Sea. Harmful Algae, 7(6), 752761. https://doi.org/10.1016/j.hal.2008.02.009

García-March, J. R. (2005). Aportaciones al conocimiento de la biología de Pinna nobilis Linneo, 1758 (Mollusca Bivalvia) en el litoral mediterráneo ibérico. [Ph.D. Thesis. Universitat de València].

García-March, J. R., \& Vicente, N. (2006). Protocol to study and monitor Pinna nobilis populations within marine protected areas. Malta Environment and Planning Authority.

García-March, J. R., García-Carrascosa, A. M., Peña Cantero, A. L., \& Wang, Y. -G. (2007). Population structure, mortality and growth of Pinna nobilis Linnaeus, 1758 (Mollusca, Bivalvia) at different depths in Moraira Bay (Alicante, Western Mediterranean). Marine Biology, 150(5), 861-871. https://doi.org/10.1007/s00227-0060386-1

García-March, J. R., Sanchís Solsona, M. Á., \& GarcíaCarrascosa, A. M. (2008). Shell gaping behaviour of Pinna nobilis L., 1758: circadian and circalunar rhythms 
revealed by in situ monitoring. Marine Biology, 153, 689698. https://doi.org/10.1007/s00227-007-0842-6

Giacobbe, S. (2002). Epibiontic mollusc communities on Pinna nobilis L. (Bivalvia, Mollusca). Journal of Natural History, 36(12), 1385-1396. https://doi.org/10.1080/00222930110056892

Gómez Hernández, M. M. (2011). Crecimiento somático y mortalidad del "callo de hacha chino" Atrina maura (Sowerby, 1835) (Mollusca: Bivalvia) durante su cultivo larvario. [Somatic growth and mortality of Penshell, Atrina maura (Sowerby, 1835) (Mollusca: Bivalvia) in larval culture]. [Ph.D. Thesis. Universidad Del Mar].

Gongora-Gomez, A., Garcia-Ulloa, M., Arellano-Martínez, M., Abad, S., Dominguez, A., \& Ponce-Palafox, J. (2016a). Annual reproductive cycle and growth of the pen shell Atrina maura (Pterioidea: Pinnidae) on sand-bottom culture in the Ensenada Pabellones lagoon system, Gulf of California, Mexico. Invertebrate Reproduction \& Development, $\quad 60(1), \quad 28-38$. https://doi.org/10.1080/07924259.2015.1126535

Góngora-Gómez, A.M., García-Ulloa, M., HernándezSepúlveda, J.A., Domínguez-Orozco, A.L., \& SainzHernández, J.C. (2016b). Crecimiento y supervivencia del callo de hacha Atrina maura (Bivalvia: Pinnidae) cultivado en la costa sureste del Golfo de California, México. [Growth and survival of pen shell Atrina maura (Bivalvia: Pinnidae) cultured in the southeastern coast of the Gulf of California, Mexico]. Revista de Biología Marina y Oceanografía, 51(3), 665-673. https://doi.org/10.4067/S0718-19572016000300017

Góngora-Gómez, A. M., Hernández-Sepúlveda, J. A., Domínguez-Orozco, A. L., Villanueva- Fonseca, B. P., \& García-Ulloa, M. (2015). Crecimiento, supervivencia y condición del callo de hacha Atrina maura (Sowerby, 1835) (Bivalvia: Pinnidae) en el estero La Piedra, Sinaloa, México. [Growth, survival and condition of the pen shell Atrina maura (Sowerby, 1835) (Bivalvia: Pinnidae) in La Piedra estuary, Sinaloa, México]. Avances en Investigación Agropecuaria, 19(3), 73-86.

Gosling, E. (2003). Bivalve molluscs: Biology, ecology and culture. Fishing News Books, Blackwell Science.

Grave, B. H. (1911). Anatomy and physiology of the wing-shell Atrina rigida. University of Michigan Library.

Gregori, M., Villón J., Jara, F., Gonzabay-Tomalá, P., \& Freites, L., (2019). Spatial and temporal spatfall of the winged pearl oyster Pteria sterna (Gould,1851), in Equatorial coasts. Aquaculture, 511, 734258 . https://doi.org/10.1016/j.aquaculture.2019.734258

Hayward, P. J., \& Ryland, J. S. (1995). Handbook of the marine fauna of north-west Europe. Oxford University Press.

Helm, M. M., \& Bourne, N. (2004). Hatchery culture of bivalves: A practical manual. FAO Fisheries Technical Paper 471 Rome, Food and Agricultural Organization of the United Nations.

Hendriks, I. E., Tenan, S., Tavecchia, G., Marbà, N., Jordà, G., Deudero, S., Álvarez, E., \& Duarte, C. M. (2013). Boat anchoring impacts coastal populations of the pen shell, the largest bivalve in the Mediterranean. Biological Conservation, 160, 105-113. https://doi.org/10.1016/j.biocon.2013.01.012

Hernandis, S., Garcia-March, J. R., Sanchís, M. A., Monleon, S., Vincente, N., \& Tena, J. (2018). Temperature regulates the switch between light-synchronized and unsynchronized activity patterns in the subtidal bivalve Pinna nobilis. Mediterranean Marine Science, 19(2), 366-375. https://doi.org/10.12681/mms.14158

Hignette, M. (1983). Croissance de Pinna nobilis Linne (Mollusque eulamelibranche) après implantation dans la réserve sous-marine de Monaco. Rapports et procèsverbaux des réunions Commission internationale pour l'exploration scientifique de la Mer Méditerranée, 28(3), 237-238.

Halla, M. I., Kassila, J., Chattou, E. M. A., Ouaggajou, Y., El Aamri, F., Benbani, A., \& Nhhala, H. (2018). Depth and seasonal effects on the settlement density of two mussel species (Perna perna and Mytilus galloprovincialis) in offshore, Agadir (Morocco). European Scientific Journal, 14(12), 229-240. https://doi.org/10.19044/esj.2018.v14n12p229

Katsanevakis, S., \& Thessalou-Legaki, M. (2009). Spatial distribution, abundance and habitat use of the protected fan mussel Pinna nobilis in Souda Bay, Crete. Aquatic Biology, 8(1), 45-54. https://doi.org/10.3354/ab00204

Katsanevakis, S. (2005). Population ecology of the endangered fan mussel Pinna nobilis in a marine lake. Endangered Species Research, 1, 51-59.

Katsanevakis, S. (2007). Growth and mortality rates of the fan mussel Pinna nobilis in Lake Vouliagmeni (Korinthiakos Gulf, Greece): a generalized additive modelling approach. Marine Biology, 152, 1319-1331. https://doi.org/10.1007/s00227-007-0781-2 
Katsanevakis, S. (2016). Transplantation as a conservation action to protect the Mediterranean fan mussel Pinna nobilis. Marine Ecology Progress Series, 546, 113-122. https://doi.org/10.3354/meps11658

Katsanevakis, S., Tsirintanis, K., Tsaparis, D., Doukas, D., Sini, M., Athanassopoulou, F., Nikolaos Kolygas, M., Tontis, D., Koutsoubas, D., \& Bakopoulos, V. (2019). The cryptogenic parasite Haplosporidium pinnae invades the Aegean Sea and causes the collapse of Pinna nobilis populations. Aquatic Invasions, 14(2), 150-164. https://doi.org/10.3391/ai.2019.14.2.01

Kawahara, I., Yamaguchi, T., Ohkuma, H., \& Ito, S. (2004). Larval rearing and metamorphosis of the pen-shell, Atrina pectinata in Ariake Sound. Bulletin of Saga Prefectural Ariake Fisheries Research and Development Centre, 22, 41-46.

Kersting, D. K., \& García-March, J. R. (2017). Long-term assessment of recruitment, early stages and population dynamics of the endangered Mediterranean fan mussel Pinna nobilis in the Columbretes Islands (NW Mediterranean). Marine Environmental Research, 130, 282-292. https://doi.org/10.1016/j.marenvres.2017.08.007

Kersting, D. K., \& Hendriks, I. E. (2019). Short guidance for the construction, installation and removal of Pinna nobilis larval collectors. IUCN. 6pp.

Kožul, V., Glavić, N, Bolotin, J., \& Antolović, N. (2013). Growth of the fan mussel Pinna nobilis (Linnaeus, 1758) (Mollusca: Bivalvia) in experimental cages in the South Adriatic Sea. Aquaculture Research, 44(1), 31-40. https://doi.org/10.1111/j.1365-2109.2011.03003.x

Kožul, V., Glavić, N., Bolotin, J., \& Antolović, N. (2011). The experimental rearing of fan mussel Pinna nobilis (Linnaeus, 1758). Proceedings of the 46th Croatian and 6th International Symposium on Agriculture, Croatia. pp. 803-806.

Kurtay, E., Lök, A., Kırtık, A., Küçükdermenci, A., \& Yiğitkurt, S. (2018). Spat recruitment of endangered Bivalve Pinna nobilis (Linnaeus, 1758) at two different depths in Izmir Bay, Turkey. Cahiers de Biologie Marine, 59(6), 501-507. http://doi.org/10.21411/cbm.a.43183913

Künili, İ. E., Ertürk Gürkan, S., Aksu, A., Turgay, E., Çakir, F., Gürkan, M., \& Altinağaç, U. (2021). Mass mortality in endangered fan mussels Pinna nobilis (Linnaeus 1758) caused by co-infection of Haplosporidium pinnae and multiple Vibrio infection in Çanakkale Strait, Turkey.
Biomarkers,

26(5),

$1-12$.

https://doi.org/10.1080/1354750X.2021.1910344

Leal-Soto, S., Barraza-Guardado, R., Castro-Longoria, R., Chávez-Villalba, J., \& Hoyos-Cháirez, F. (2011). Cultivation of pen shells: an example with Atrina maura in Northwestern Mexico. Journal of the World Aquaculture Society, 42(6), 789-800. https://doi.org/10.1111/j.1749-7345.2011.00528.x

Lee, Y.-J., Choi, K.-S., Lee, D.-S., Lee, W.C., Park, H.J., Choy, E.J., Kim, H.C., \& Kang, C.-K. (2015). The role of the adductor muscle as an energy storage organ in the pen shell Atrina japonica (Reeve, 1858). Journal of Molluscan Studies, $\quad$ 81(4), 502-511. https://doi.org/10.1093/mollus/eyv025

Leyva-Valencia, I., Maeda-Martínez, A.N., Sicard, M.T., Roldan, L., \& Robles-Mungaray, M. (2001). Halotolerance, upper thermotolerance, and optimum temperature for growth of the penshell Atrina maura (Sowerby, 1835) (Bivalvia: Pinnidae). Journal of Shellfish Research, 20(1), 49-54.

Liang, X. Y., \& Morton, B. (1988). The pallial organ of Atrina pectinata (Bivalvia: Pinnidae): its structure and function. Journal of Zoology, 216(3), 469-477. https://doi.org/10.1111/j.1469-7998.1988.tb02443.x

Lodeiros, C., Pico, D., Prieto, A., Narváez, N., \& Guerra, A. (2002). Growth and survival of the pearl oyster Pinctada imbricata (Röding 1758) in supended and bottom culture in the Golfo de Cariaco, Venezuela. Aquaculture International, $10(4)$, 327-338. https://doi.org/10.1023/A:1022451608405

Lök, A., \& Acarli, S. (2006). Preliminary settlement studies of flat oyster (Ostrea edulis, L.) on oyster and mussel shell collectors in Karantina Island (Turkey). The Israeli Journal of Aquaculture-Bamidgeh, 58(2), 105-115. https://doi.org/10.46989/001c.20434

Lök, A., \& Yolkolu, S. (1999). İstiridye yavrularının (spat) toplanmasında kullanılan kollektör tipleri. Sualtı Bilim ve Teknolojisi Toplantısı Bildiriler Kitabı, Turkey. pp. 109-113.

Maeda-Martínez, A. N. (2008). Estado actual del cultivo de bivalvos en México. In Lovatelli, A., Farías, A., Uriarte, I. (Eds.), Estado actual del cultivo y manejo de moluscos bivalvos y su proyección futura: factores que afectan su sustentabilidad en América Latina. Taller Técnico Regional de la FAO, 20-24 de agosto de 2007. Puerto 
Montt, Chile, FAO Actas de Pesca y Acuicultura, No 12. Roma. FAO. pp. 91-100.

Maeno, Y., Suzuki, K., Yurimoto, T., Fuseya, R., Kiyomoto, S., Ohashi, S., \& Oniki, H. (2009). Maturation process of broodstock of the pen shell Atrina pectinata (Linnaeus, 1767) in suspension culture. Journal of Shellfish Research, 28(3), 561-568. https://doi.org/10.2983/035.028.0319

McCoy E. W., \& Chongpeepien, T. (Eds.) (1988). Bivalve Mollusc Culture Research in Thailand. ICLARM Technical Reports 19. Department of Fisheries, Bangkok, Thailand; International Center for Living Aquatic Resources Management, Manila, Philippines; and Deutsche Gesellschaft für Technische Zusarnmenarbeit (GTZ), GmbH, Eschborn, Federal Republic of Germany.

Mendo, T., Koch, V., Wollf, M., Sínsel, F., \& Ruiz-Verdugo, C. (2011). Feasibility of intertidal bottom culture of the penshell Atrina maura in Bahia Magdalena, Baja California Sur, Mexico. Aquaculture, 314(1-4), 252-260. https://doi.org/10.1016/j.aquaculture.2011.01.044

Mihailinović, M. (1955). Lostura. Morsko Ribarstvo, 7(5), 113114.

Miranda-Baeza, A. (1995). El callo de hacha, un molusco con gran potencial en acuacultura. Panorama Acuícola 1, 12-13.

Morton, B., \& Puljas, S. (2019). An improbable opportunistic predator: the functional morphology of Pinna nobilis (Bivalvia: Pterioida: Pinnidae). Journal of the Marine Biological Association of the United Kingdom, 99(2), 359373. https://doi.org/10.1017/S0025315418000267

Najdek, M., Blažina, M., Ezgeta-Balić, D., \& Pherda, M. (2013). Diets of fan shells (Pinna nobilis) of different sizes: fatty acid profiling of digestive gland and adductor muscle. Marine Biology, 160(4), 921-930. https://doi.org/10.1007/s00227-012-2144-X

Narváez, N., Lodeiros, C., Freites, L., Núñez, M., Pico, D., \& Prieto, A. (2000). Abundance and growth of Pinna carnea (Mytiloida: Pinnacea) juveniles in suspendedframe culture. Revista de Biología Tropical, 48(4), 785797.

Natalotto, A., Sureda, A., Maisano, M., Spanò, N., Mauceri, A., \& Deudero, S. (2015). Biomarkers of environmental stress in gills of Pinna nobilis (Linnaeus 1758) from Balearic Island. Ecotoxicology and Environmental
Safety, 122,

9-16.

https://doi.org/10.1016/j.ecoenv.2015.06.035

Ohashi S., Fujii, A., Oniki H., Osako, K., Maeno, Y., \& Yoshikoshi, K. (2008). The rearing of the pen shell Atrina pectinata larvae and juveniles (Preliminary note). Aquaculture Science, 56(2), 181-191.

Öndes, F., Alan, V., Akçalı, B., \& Güçlüsoy, H. (2020). Mass mortality of the fan mussel, Pinna nobilis in Turkey (eastern Mediterranean). Marine Ecology, 41(5), e12607. https://doi.org/10.1111/maec.12607

Powell, E. N., Klinck, J. M., Hofmann, E. E., \& Ford, S. (1997). Varying the timing of oyster transplant: implications for management from simulation studies. Fisheries Oceanography, 6(4), 213-237

Qiu, T., Zhang, T., Bai, Y., Xue, D., \& Pan, Y. (2014). Gonad development of the pen shell Atrina pectinata from Shandong Province, China. Journal of Shellfish Research, 33(2), 465-471. https://doi.org/10.2983/035.033.0215

Rabaoui, L., Belgacem, W., Ismail, D. B., Mansour L., \& TligZouari, S. (2015). Engineering effect of Pinna nobilis shells on benthic communities. Oceanologia, 57(3), 271279. https://doi.org/10.1016/j.oceano.2015.03.002

Rabaoui, L., Zouari, S. T., \& Hassine, O. K. B. (2008). Two species of Crustacea (Decapoda) associated with the fan mussel, Pinna nobilis Linnaeus, 1758 (Mollusca, Bivalvia). Crustaceana, 81(4), 433-446. https://doi.org/10.2307/20111407

Richardson, C. A., Peharda, M., Kennedy, H., Kennedy, P., \& Onofri, V. (2004). Age, growth rate and season of recruitment of Pinna nobilis (L) in the Croatian Adriatic determined from $\mathrm{Mg}$ : $\mathrm{Ca}$ and $\mathrm{Sr}$ : $\mathrm{Ca}$ shell profiles. Journal of Experimental Marine Biology and Ecology, 299(1), 1-16. https://doi.org/10.1016/j.jembe.2003.08.012

Richardson, C. A., Kennedy, H., Duarte, C. M., Kennedy, D. P. \& Proud, S. V. (1999). Age and growth of the fan mussel Pinna nobilis from south-east Spanish Mediterranean seagrass (Posidonia oceanica) meadows. Marine Biology, 133, 205-212. https://doi.org/10.1007/s002270050459

Roberts, D. (1984). A comparative study of Lasaea australis, Vulsella spongiarum, Pinna bicolor and Donacilla cuneata (Mollusca; Bivalvia) from Princess Royal Harbour, Western Australia, Journal of Molluscan Studies, 50(3),

129-136. https://doi.org/10.1093/oxfordjournals.mollus.a065859

Robles-Mungaray, M. (2004). Desarrollo de la biotecnología para la producción de semilla en laboratorio, diploide $y$ 
triploide de callo de hacha Atrina maura (Sowerby, 1835). [M.Sc. Thesis. Universidad Autónoma de Baja California Sur].

Rouanet, E., Trigos, S., \& Vicente, N. (2015). From youth to death of old age: the 50-year story of a Pinna nobilis fan mussel population at Port-Cros Island (Port-Cros National Park, Provence, Mediterranean Sea). Scientific Reports of Port-Cros National Park, 29, 209-222.

Ruitton, S., \& Lefebvre, C. (2021). Toward a recovery of the pen shell Pinna nobilis in the French Mediterranean open sea?. Scientific Reports of the Port-Cros National Park, 35, 429-434.

Safi, K. A., Hewitt, J. E., \& Talman, S. G. (2007). The effect of high inorganic seston loads on prey selection by the suspension-feeding bivalve, Atrina zelandica. Journal of Experimental Marine Biology and Ecology, 344(2), 136148. https://doi.org/10.1016/j.jembe.2006.12.023

Saucedo, P. E., Bervera-León, H., Monteforte, M., Southgate, P., \& Monsalvo-Spencer, P. (2005). Factors influencing recruitment of hatchery reared pearl oyster (Pinctada mazatlanica, Hanley 1856) spat. Journal of Shellfish Research, 24(1), 215-219.

Savun-Hekimoğlu, B., \& Gazioğlu, C. (2021). Mucilage problem in the semi-enclosed seas: recent outbreak in the Sea of Marmara. International Journal of Environment and Geoinformatics, 8(4), 402-413. https://doi.org/10.30897/ijegeo.955739

Schiaparelli, S., Castellano, M., Povero, P., Sartoni, G., \& Cattaneo-Vietti, R. (2007). A benthic mucilage event in North-Western Mediterranean Sea and its possible relationships with the summer 2003 European heatwave: short term effects on littoral rocky assemblages. Marine Ecology, 28(3), 341-353. https://doi.org/10.1111/j.1439-0485.2007.00155.x

Simide, R., Couvray, S., \& Vicente, N. (2019). Présence de Pinna nobilis (L. 1758) dans l'étang littoral de Diana (Corse). [Presence of Pinna nobilis (L.1758) in the littoral pond of Diana (Corsica)]. Marine Life, 2019, 1-4.

Soria, G., Lavín, M. F., \& Cudney-Bueno, R. (2015). Spat availability of commercial bivalve species recruited on artificial collectors from the northern Gulf of California. Seasonal changes in species composition. Aquaculture Research, 46(12), 2829-2840. https://doi.org/10.1111/are.12435

Tebble, N. (1966). British Bivalve Seashells A Hand Book Identification, Trustees of The British Museum, London.
Theodorou, J. A., James, R., Tzovenis, I., \& Hellio, C. (2015). The recruitment of the endangered fan mussel (Pinna nobilis L.1758) on the ropes of a Mediterranean mussel long line farm. Journal Shellfish Research, 34(2), 409414. https://doi.org/10.2983/035.034.0224

Sergio, T., \& Vicente, N., (2016). Protocole pour la transplantation des nacres Pinna nobilis dans divers substrats. [Transplantation protocol for the fan mussel Pinna nobilis in different types of substrate]. Marine Life, 18, 55-61

Trigos, S., García-March, J. R., Vicente, N., Tena, J., \& Torres, J. (2014). Utilization of muddy detritus as organic matter source by the fan mussel Pinna nobilis. Mediterranean Marine Science, 15(3), 667-67

Trigos, S., Vicente, N., Prado, P., \& Espinós, F. J. (2018). Adult spawning and early larval development of the endangered bivalve Pinna nobilis. Aquaculture, 483, 102-110. https://doi.org/10.1016/j.aquaculture.2017.10.015

Vázquez-Luis, M., Álvarez, E., Barrajón, A., García-March, J. R., Grau, A., Hendriks, I. E., Jiménez, S., Kersting, D., Moreno, D., Pérez, M., Ruiz, J. M., Sánchez, J., Villalba, A., \& Deudero, S. (2017). S.O.S. Pinna nobilis: A mass mortality event in Western Mediterranean Sea. Frontiers in Marine Science, 4, 220. https://doi.org/10.3389/fmars.2017.00220

Velasco, L. A., \& Barros, J. (2010). Spat collection and experimental culture of the Atlantic pearl oyster, Pinctada imbricata (Bivalvia: Pteriidae), under suspended conditions in the Caribbean. Journal of the World Aquaculture Society, 41(3), 281-297. https://doi.org/10.1111/j.1749-7345.2010.00371.x

Velasco, L. A., \& Borrero, F. J. (2004). Captacíon desemilla y cultivo experimental del hacha Pinna carnea Gmelin, 1971 (Bivalvia: Pinnidae) en el parquenatural Tayrona, Caribe Colombiano. [Seed collection and experimental culture of the pen shell Pinna carnea Gmelin, 1791 (Bivalvia: Pinnidae) in the Tayrona National Natural Park, Colombian Caribbean]. Revista Intropica, 1, 75-83.

Vicente, N., \& Moreteau, J.-C. (1991). Statut de Pinna nobilis L. en Méditerranée (Mollusque eulamellibranche) (pp. 159-168). In Boudouresque, C. F., Avon, M., Gravez, V. (Eds.), Les Espèces Marines à Protéger en Méditerranée. GIS Posidonie Publishing.

Vicente, N., Moreteau, J. C., \& Escoubet, P. (1980). Etude de l'évolution d'une population de Pinna nobilis L. (mollusque eulamellibranche) au large de l'anse de la 
Palud (Parc National sous-marin de Port-Cros). Travaux Scientifiques du Parc National de Port-Cros, 6, 39-67.

Wang, C., Qi, L., Xu, C., \& Yu, R. (2017). Seasonal changes of reproductive activity and biochemical composition of pen shell Atrina pectinata Linnaeus, 1767 in Bohai Sea China. Oceanic and Coastal Sea Research, 16, 479-489. https://doi.org/10.1007/s11802-017-3212-0

Wu, R. S. S., \& Shin, P. K. S. (1998). Transplant experiments on growth and mortality of the fan mussel Pinna bicolor. Aquaculture, 163(1-2), 47-62. https://doi.org/10.1016/S0044-8486(98)00218-X

Yang, Q., Li, Q., RH, Yu, Li, J. (2006) Artificial induction of gynogenesis in Atrina pectinata. Journal of Fishery Sciences of China, 13(2), 310-315

Yiğitkurt, S., Lök, A., Kırtık, A., Küçükdermenci, A., \& Kurtay, E. (2017). Preliminary results of spat collection of Rayed pearl oyster (Pinctada radiata) in Turkey. Ege Journal of Fisheries and Aquatic Sciences, 34(2), 11-218. https://doi.org/10.12714/egejfas.2017.34.2.13

Yildiz, H., Lök, A., Acarlı, S., Serdar, S., Kucukdermenci, A., Berber, S., \& Vural, P. (2013). Influences of different collector materials on Mediterranean mussel, Mytilus galloprovincialis L. 1819 in the Dardanelles. Marine Science and Technology Bulletin, 2(1):23-35.
Yildiz, H., Lök, A., Serdar, S., Acarlı, S., \& Köse, A. (2005). Çanakkale Boğazında Yavru (Spat) Midyelerin (Mytilus galloprovincialis Lamarck, 1819) Yapay Kollektörlere Tutunma ve Büyüme Performansları. [Mussel (Mytilus galloprovincialis Lamarck, 1819) spat settlement and growth performances on artificial collectors in Dardanelles]. Ege Journal of Fisheries and Aquatic Sciences, 22(3-4), 257-261.

Yonge, C. M. (1953). Form and Habit in Pinna carnea Gmelin. Philosophical Transactions of the Royal Society of London. Series B, Biological Sciences, 237(648), 335-374.

Zavodnik, D., Hrs-Brenko, M., \& Legac, M. (1991). Synopsis on the fan shell Pinna nobilis L. in the eastern Adriatic Sea (pp. 169-178). In: Boudouresque, C. F., Avon, M., \& Gravez, V. (Eds.), Les Espèces Marines à Protéger en Méditerranée. GIS Posidonie Publishing.

Zotou, M., Gkrantounis, P., Karadimou, E., Tsirintanis, K., Sini, M., Poursanidis, D., Azzolin, M., Dailianis, T., Kytinou, E., Issaris, Y., Gerakaris, V., Salomidi, M., Lardi, P., Ramfos, A., Akrivos, V., Spinos, E., Dimitriadis, C., Papageorgiou, D., Lattos, A., Giantsis, I., Michaelidis, B., Vassilopoulou, V., Miliou, A., \& Katsanevakis, S. (2020). Pinna nobilis in the Greek seas (NE Mediterranean): on the brink of extinction?. Mediterranean Marine Science, 21(3), 575-591. https://doi.org/10.12681/mms.23777 